
DENITRIFIED DOMESTIC WASTEWATER THROUGH TWO ARTIFICIALLYCREATED SOILS

b Research associate, Institut national de la recherche scientifique (Centre Eau, Terre et

11 Environnement), Université du Québec, 490 rue de la Couronne, Québec, Qc, Canada,

12 G1K 9A9, Phone: (418) 654-3793, Fax: (418) 654-2600, email: lucie.coudert@ete.inrs.ca

13 c Project manager, PREMIER TECH, 1 avenue Premier Campus Premier Tech, Rivière-du14 Loup, Qc, Canada, G5R 6C1, Phone: (418) 867-8883, Fax: (418) 862-6642, email:

\title{
15 gily@premiertech.com
}

$16 \mathrm{~d}$ Professor, Institut national de la recherche scientifique (Centre Eau, Terre et Environnement), 17 Université du Québec, 490 rue de la Couronne, Québec, Qc, Canada, G1K 9A9, Phone: (418) 18 654-2633, Fax: (418) 654-2600, email: guy.mercier@ete.inrs.ca

19 e Professor, Institut national de la recherche scientifique (Centre Eau, Terre et Environnement), 20 Université du Québec, 490 rue de la Couronne, Québec, Qc, Canada, G1K 9A9, Phone: (418) 21 654-2575, Fax: (418) 654-2600, email: blaisjf@ete.inrs.ca

$23 *$ Corresponding author 


\section{Abstract}

29 This study focused on a pilot scale infiltration of denitrified wastewater through artificially-

30 created soils. The hydraulic performance and sulfide production were evaluated to ensure the

31 system's longevity over the time period needed for autotrophic denitrification. Experiments were

32 carried out over a year in two reactors of 200-L capacity. Sandy and sandy loam soils were tested

33 to represent highly permeable $(\mathrm{Ks}=0.028 \mathrm{~cm} / \mathrm{s})$ and permeable $(\mathrm{Ks}=0.0013 \mathrm{~cm} / \mathrm{s})$ soils,

34 respectively. The infiltration of denitrified wastewater at a continuous hydraulic rate (130 and

$3570 \mathrm{~L} / \mathrm{m}^{2} /$ day) through these soils did not lead to the production of large amounts of gaseous

36 hydrogen sulfide $\left(\left[\mathrm{H}_{2} \mathrm{~S}\right]<2.1 \mathrm{ppm}\right)$ or aqueous sulfides $\left(\left[\mathrm{HS}^{-}+\mathrm{H}_{2} \mathrm{~S}\right]<0.7 \mathrm{mg} / \mathrm{L}\right)$ sulfides in both

37 feeding inffluent and effluents of the 200-L reactors. Considering the hydraulic performance, no

38 loss in the infiltration capacity was recorded for the sandy soil, whereas a clogging phenomenon

39 was observed after 37 days for the sandy loam soil. Two factors were responsible for this

40 clogging phenomenon. A fine brown layer, known as a biomat, was formed on the infiltrative

41 surface (IS) of the soil, which led to the formation of iron ochre at the bottom of the reactor. As

42 an ascertainment due to the clogging phenomenon faced, sandy soil appeared to be the best

43 choice as it didn't contain organic matter, which could lead to the biomat formation and 44 therefore, to a clogging phenomenon.

46 Keywords: domestic wastewater; autotrophic denitrification; sulfide generation; clogging 47 phenomenon. 


\section{INTRODUCTION}

In rural areas, residential wastewater is usually managed using an on-site wastewater

50 system, commonly called septic systems. According to Canada Statistics (2011), 13.3 M

51 households were not connected to a centralized system. Among them, $1 \mathrm{M}$ are in the province of

52 Quebec (MDDEFP, 2013). A septic system typically consists firstly in a physical treatment using

53 a septic tank. The septic tank ensures the settling of heavy solids to form a sludge and the

54 flotation of the light suspended solids and grease to form a scum layer. According to MDDELCC

55 (2015), discharge standard requires that suspended solids in wastewater from septic tank should

56 be lower than $100 \mathrm{mg} / \mathrm{L}$. In addition to the septic tank, the wastewater joins a drain field which

57 ensures the biodegradation of organic matter and the reduction of pathogenic organisms. Studies

58 on the effectiveness of underground disposal shows that wastewater has a high acceptable quality

59 in terms of Biochemical Oxygen Demand after 5 days $\left(\mathrm{BOD}_{5}\right)$, suspended solid, phosphorus,

60 nitrogen. According to these studies, fecal coliforms are closed to zero. However, depending on

61 the local regulations, more compact biological processes, such as aerobic treatment units (ATUs)

62 or biofilters, can be installed after the septic tank, replacing drain fields (Buchanan, 2014). In

63 such cases, the treated wastewater flows to an infiltration bed (sometimes referred to as a

64 polishing bed) into which it infiltrates. Thus, the treated wastewater undergoes an additional

65 purification step through the soil before reaching the groundwater. This purification zone allows

66 further filtration of particulates and biomass growth and provides low-cost reduction in the

67 concentrations of some contaminants (Lowe and Siegrist, 2008). However, some deficiencies can

68 remain because of the biological, chemical and/or physical interactions that occur between the

69 intrinsic components of the soils and the remaining residual contaminants in treated wastewater

70 (Baveye et al., 1998). 
The infiltration capacity is mainly evaluated by the saturated hydraulic conductivity (Ks),

72 which measures the ability of soil to transmit water (Lindbo, 2014). For example, the hydraulic

73 conductivity of highly restrictive soil such as clay is 100 to 1000 times lower than that of highly

74 permeable sandy soils (Baveye et al., 1998). According to Lowe and Siegrist (2008), sandy and

75 sandy silty soils exhibit good infiltration and follow an unsaturated flow regime. Over time, with

76 a continuous infiltration of effluent, wastewater can reach the saturated hydraulic conductivity

77 zone of a soil. Furthermore, after a long period of constant wastewater infiltration, a biozone or

78 biomat might form on the infiltration surface (IS) (Lowe and Siegrist, 2008). Both of these

79 phenomena are due to the accumulation of microbial biomass and/or organic matter in the soil

80 (Lowe and Siegrist, 2008). These phenomena are usually welcomed, as they result in more

81 uniform infiltration and, to a certain degree, better wastewater purification through

82 biotransformation and/or sorption of the contaminants (Hargett et al., 1981; Lowe and Siegrist,

83 2008; Siegrist and Thresher, 1985). However, over time, the infiltration capacity of treated

84 wastewater through the soil seems to be influenced by the nature of the biomat. According to

85 White and West (2003), the formation and nature of a biomat have a more important effect on

86 the infiltration of treated wastewater than the initial soil permeability. Acting as a barrier, the

87 biomat influences the infiltration capacity of the treated wastewater through the soil, leading to a

88 clogging phenomenon, which enhances hydraulic failure and oxygen depletion, leading to

89 anaerobic conditions in the soil (Siegrist and Thresher, 1985). Many biological and chemical

90 reactions could occur depending on the components present in both treated wastewater and soil.

91 Therefore, it is important to ensure the harmlessness of the by-products. 
Many studies investigated the performance of an autotrophic denitrification system to

93 reduce nitrates to nitrogen gas from the water using elemental sulfur (Equation 1) (Ben-Khaled,

94 2016; Christianson et al., 2015; Kimura et al., 2002; Soares, 2002; Van Der Hoek et al., 1992).

$$
5 \mathrm{~S}^{0}+6 \mathrm{NO}_{3}^{-}+6 \mathrm{H}_{2} \mathrm{O} \rightarrow 3 \mathrm{~N}_{2}+4 \mathrm{H}_{3} \mathrm{O}^{+}+5 \mathrm{SO}_{4}{ }^{2-}
$$

Ben-Khaled (2016) used elemental sulfur and limestone in an on-site treatment system. In

99 another study, elemental sulfur and oyster shells were also shown to be highly efficient in

100 removing nitrates and nitrites (100\% nitrate removal), with initial concentrations ranging from

10125 to $30 \mathrm{mg} / \mathrm{L}$ from marine water systems (Simard et al., 2015). In these processes, denitrifying

102 bacteria use nitrate as an electron acceptor, sulfur as an electron donor and an inorganic source of

103 carbon such as $\mathrm{CO}_{2}$ and $\mathrm{HCO}_{3}^{-}$(Zhang and Shan, 1999). The main advantage of these processes

104 is that no external carbon is required. However, one of the main drawbacks is the release of high

105 quantities of sulfates $(100-200 \mathrm{mg} / \mathrm{L})$, the degree to which depends on the initial concentration of

106 nitrate ions present in water and the removal capacity of the process used.

107 Despite the fact that many studies pointed out the high performances of nitrate removals

108 from wastewater using an autotrophic denitrification process, few of them were interested in the 109 potential production of sulfides following Equations 2 and 3.

$$
2 \mathrm{CH}_{2} \mathrm{O}+\mathrm{SO}_{4}{ }^{2-} \rightarrow 2 \mathrm{HCO}_{3}^{-}+\mathrm{H}_{2} \mathrm{~S}
$$


113 Table 1 summarizes some recent researches related to the potential release of sulfide 114 products from denitrified groundwater or domestic wastewater. Among these studies, Zhang and 115 Shan (1999) mentioned a sulfide concentration ranging from 1.5 to $10 \mathrm{mg} / \mathrm{L}$ during the treatment 116 of an effluent from a septic tank, using sulfur and limestone. Otherwise, the other authors briefly 117 mentioned that the production of sulfide products is very low, without quantifying them (Sierra118 Alvarez et al., 2007; Xu et al., 2016). Meanwhile, other workers did not detect sulfide generation 119 while removing nitrates from groundwater (Kimura et al., 2002; Soares, 2002).

120 According to the Eh-pH diagram, sulfide may be present in liquid phase under different forms

$121\left(\mathrm{H}_{2} \mathrm{~S}, \mathrm{HS}^{-}\right.$or $\left.\mathrm{S}^{2-}\right)$ (Lens and Hulshoff Pol, 2004). However, only the molecular sulfide form $\left(\mathrm{H}_{2} \mathrm{~S}\right)$ can be 122 distributed between the gas and the liquid phases. These concentrations are related to the solubility of $123 \mathrm{H}_{2} \mathrm{~S}_{(\mathrm{aq})}$ and the partial pressure in air following the Equation 4, involving the Henry's law constant $\left(\mathrm{K}_{\mathrm{H}}\right)$. 124 For instance, the Henry's law constant is estimated at $0.131 \mathrm{~mol} / \mathrm{L} / \mathrm{bar}$ at $1 \mathrm{bar}$ and $15^{\circ} \mathrm{C}(\operatorname{Reddy}$ 125 and DeLaune, 2008).

$$
\left[\mathrm{H}_{2} \mathrm{~S}\right]_{\mathrm{aq}}=\mathbf{K}_{\mathrm{H}} \mathbf{P}_{\mathrm{H} 2 \mathrm{Sg}}
$$

129 where $\left[\mathrm{H}_{2} \mathrm{~S}\right]_{a q}$ is the concentration of $\mathrm{H}_{2} \mathrm{~S}$ in liquid phase (mol/L), $K_{H}$ is the Henry's law 130 constant ( $\mathrm{mol} / \mathrm{L} / \mathrm{bar}$ ) and $\mathrm{P}_{\mathrm{H} 2 \mathrm{Sg}}$ is the partial pressure of $\mathrm{H}_{2} \mathrm{~S}$ in the air (bar).

During the infiltration of denitrified wastewater (DW) through the soil, the sulfate133 reducing bacteria (SRB) present in soils can use the organic matter as electron donors and the 134 sulfates as electron acceptors, resulting in the reduction of sulfate to sulfide (Zhou et al., 2011). 
135 Sulfide generation could be responsible for many bad effects such as negative impacts on human 136 health, unpleasant odor and corrosion. The effects of sulfide on human health vary from a simple 137 olfactory irritation to severe lung irritation, dizziness and collapse leading to death within $4-8 \mathrm{~h}$ 138 after exposure (above 500 ppm) (Beauchamp et al., 1984; Chou, 2003; Glass, 1990; Partlo et al., 139 2001; Reiffenstein et al., 1992). All these drawbacks could highly affect septic system 140 performance and be harmful for users. The SRB activity is dependent upon factors such as the 141 temperature, the $\mathrm{pH}$ of the wastewater, anaerobic conditions and the availability of a 142 biodegradable carbon source (Barton and Hamilton, 2007). Liang (2008) emphasizes that a 143 temperature varying between 28 and $32^{\circ} \mathrm{C}$ is optimum for most SRB. Moreover, the SRB species 144 usually exist in a range of pH varying between 5.5 and 9.0 (Liang, 2008; Nielsen et al., 1998). 145 Thus, the SRB are able to produce sulfide under the usual $\mathrm{pH}$ and temperature conditions 146 encountered in soils. Anaerobic environments are highly dependent on the Oxidation Redox 147 Potential (ORP) of the media, which should be lower than $-100 \mathrm{mV}$ to support SRB activity 148 (Abhilash et al., 2015; Huan et al., 2013). Some SRB species can use $\mathrm{H}_{2}$ as an electron donor or, 149 more commonly, simple or complex organic matter such as propionate, butyrate, lactate, ethanol, 150 pyruvate, malate, fumarate and glycerol (Liu et al., 2015).

151 Over the last years, many researchers have developed autotrophic denitrification 152 processes to meet the regulations, which are more stringent in terms of contaminant releases 153 from wastewater to the environment and especially nitrates. Despite the fact that these processes 154 allowed the decrease of the concentration of nitrate below $5 \mathrm{mg} \mathrm{NO}_{3}{ }^{-} \mathrm{-N} / \mathrm{L}$, avoiding 155 eutrophication and cyanobacteria developments, they require a better understanding of the 156 behavior of by-products generated such as sulfate to ensure the safety of these processes. In this 157 context, this research project aims to ensure that there is no generation of by-products during the 
158 denitrification of domestic wastewater using elemental sulfur and limestone, which can represent

159 a potential risk for the environment. More specifically, it was necessary to ensure that there is no

160 reduction of sulfates into aqueous and/or gaseous sulfides during the infiltration of the denitrified

161 wastewater through soils having different permeabilities at a pilot scale.

162 MATERIALS AND METHODS

\section{Experimental set-up}

164 Pilot-scale experiments were conducted at an experimental wastewater treatment station

165 located in Rivière-du-Loup (Quebec, QC, Canada). Figure 1 presents a schematic diagram of the

166 septic system used at the experimental treatment station. During the sampling period, the average

167 temperature in the city varied between -29.8 and $+22.7^{\circ} \mathrm{C}$ (Canada, 2014-2015). However, for

168 decentralized residential sites, the temperature of the raw wastewater exiting a house rarely drops

169 below $10^{\circ} \mathrm{C}$.

170 As shown in Figure 2 (a, b), two 200-L-capacity reactors (internal diameter of $58 \mathrm{~cm}$ and

171 height of $95 \mathrm{~cm}$ ) made of high-density polyethylene (HDPE) were installed at the experimental

172 wastewater station. These experiments were carried out over a year using two different soil

173 samples [sandy (100\% sand) and sandy loam (85\% sand-15\% loam)]. The sand used for these

174 experiments was obtained from Biomix (Quebec, QC, Canada), while the loam fraction used in

175 the soil mixture was collected along the St. Charles River (Quebec, QC, Canada) and passed

176 through a 53- $\mu \mathrm{m}$ sieve. The loam fraction was then mixed with a beach sand fraction $(15 \%-85 \%)$

177 to obtain the targeted properties of a permeable soil. The gravel, devoid of its fine particles,

178 represents the distribution system over the infiltration area and was of a size greater than or equal

179 to $1.5 \mathrm{~cm}$. Approximately $180 \mathrm{~kg}$ of sand was used to fill the first reactor $(60 \mathrm{~cm}$ in height),

180 while a mixture of $105.5 \mathrm{~kg}$ of sand and $18.6 \mathrm{~kg}$ of loam was used to fill the second reactor 
181 (30 cm in height). Actually, the septic field design was based on the regulation established by the 182 Province of Quebec (MDDELCC, 2015). According to this regulation, soil height depends on its 183 permeability (highly permeable and permeable soils require 60 and $30 \mathrm{~cm}$ of natural soil, 184 respectively). Moreover, this regulation indicates that the septic field should be composed of 185 back fill $(60 \mathrm{~cm})$, gravel $(30 \mathrm{~cm})$ and natural soil $(30$ or $60 \mathrm{~cm})$, which represents at least $120 \mathrm{~cm}$ 186 depth (3.93 ft depth). Bulk densities were measured according to the real diameter of $50 \mathrm{~cm}$ 187 instead of $58 \mathrm{~cm}$ (presence of tarpaulin and plastic layers). Thus, sand reactor density was 188 estimated at $1.52 \mathrm{~g} / \mathrm{cm}^{3}$ (calculated by using the diameter of $50 \mathrm{~cm}$ and the height of $60 \mathrm{~cm}$ for 189 the volume and $180000 \mathrm{~g}$ for the mass), while, the bulk density of the sandy loam reactor was 190 estimated at $2.1 \mathrm{~g} / \mathrm{cm}^{3}$ (calculated by using the diameter of $50 \mathrm{~cm}$ and the height of $30 \mathrm{~cm}$ for the 191 volume and $124100 \mathrm{~g}$ for the mass).

192 Denitrified domestic wastewater

The pilot-scale reactors were fed in semi-continuous mode with DW emerging from a 194 decentralized wastewater treatment plant, producing approximately 1500 L/day (representative 195 of a residence with three bedrooms) (MDDELCC, 2015). Table 2 summarizes the main 196 characteristics of this DW (the influent of the present study). Then, the reactors were daily 197 supplied with fresh denitrified wastewater, which was twice a week collected and characterized 198 with reactors effluents during the 365 days of experiments. The entire process chain consisted of 199 a septic tank, an organic-based biofilter and a sulfur- and limestone-based autotrophic 200 denitrification reactor (Figure 1). This latter allows to reach nitrate concentration, during the 201 sampling period, under $5 \mathrm{NO}_{3}{ }^{-} \mathrm{N}-\mathrm{mg} / \mathrm{L}$.

202 To simulate a conventional infiltration of the treated wastewater through the soil, two 203 multichannel peristaltic pumps were used to deliver the wastewater continuously into the reactors 
204 during the feeding period via a system that allowed for homogeneous distribution over the entire

205 surface of the reactor, thus avoiding the surface effect (Figure 2c.). The feeding period (supply

206 sequences) lasted $3 \mathrm{~h}$ each day (from 8 a.m. to 9 a.m., from 10 a.m. to 11 a.m. and from 12 p.m.

207 to 1 p.m.). In the present study, the wastewater loading rates were based on an isolated three-

208 bedroom household (MDDELCC, 2015). Based on the regulation established by the Province of

209 Quebec concerning the infiltration of domestic wastewater (MDDELCC, 2015), the infiltration

210 of denitrified wastewater through different soils using typical hydraulic loading rates (HLR)

$211\left(65 \mathrm{~L} / \mathrm{m}^{2} /\right.$ day for the highly permeable soil and at $35 \mathrm{~L} / \mathrm{m}^{2} /$ day for the permeable soil) has

212 already been studied at laboratory scale (Ghorbel et al., 2016). The results obtained at laboratory

213 scale showed that no important sulfide generation occurs after 104 days of experiments. Thus,

214 the HLR was doubled to get results in a reasonable experimental timeframe but also to afford

215 favorable conditions for sulfide generation (higher sulfate and organic matter concentrations)

216 (Lowe and Siegrist, 2008). Therefore, the daily HLRs were set at 130 and $70 \mathrm{~L} / \mathrm{m}^{2} /$ day for the

217 highly permeable and permeable soils, respectively. Twice a week, samples of approximately

$218240 \mathrm{~mL}$ were collected from the bottom of the reactors. Various parameters were measured on-

219 site at the inlet and outlet of the reactors.

220 Determination of soil sample permeability

221 The hydraulic conductivities of both sandy and sandy loam soils were determined using a 222 constant load test according to Darcy's Law based on Longpré-Girard et al. (2016) and Martel 223 and Gélinas (1996). For this purpose, a 2.54-cm-diameter and 45-cm high column was used. The

224 soil was gradually introduced into the column and compacted to obtain a relative soil density of

$2251.8 \mathrm{~g} / \mathrm{cm}^{3}$. Two types of saturation were then applied to the system. First, carbon dioxide $\left(\mathrm{CO}_{2}\right)$

226 was circulated at low pressure (3 - $5 \mathrm{psi}$ ) for $30 \mathrm{~min}$, and then, upward flowing water saturation 
227 was applied using a Mariotte vessel (Musy and Soutter, 1991). The first $\mathrm{CO}_{2}$ saturation was

228 applied to remove the oxygen, while the second water saturation was conducted to provide a 229 constant pressure head on the tested material. According to Darcy's Law, the permeability (Ks)

230 was determined by measuring the outlet flow from the column as follows:

$$
\mathbf{K s}=\mathbf{Q} \mathbf{L} / \mathbf{S} \Delta \mathbf{h}
$$

234 where $K s$ is the permeability coefficient $(\mathrm{cm} / \mathrm{s}), S$ is the cross-sectional area of the column $235\left(\mathrm{~cm}^{2}\right), L$ is the column length $(\mathrm{cm})$, Sh is the loading difference between the input and output (cm) 236 and $Q$ is the outlet flow rate $\left(\mathrm{cm}^{3} / \mathrm{s}\right)$.

\section{Analytical methods}

A laser particle sizer (Partica Laser Scattering LA-950V2, Laser Particle Size Analyzer,

240 Tokyo, Japan) was used to determine the particle size distribution of the different soil samples.

241 The concentration of the organic carbon present in the soils was determined using a 242 CHNS Leco Analyzer (TruSpec Micro, Michigan, MI, USA). During each series of 243 measurement, two certified control powders have been used (Sulfamethazine from USA and 244 OAS from UK) to check the accuracy of the results. The concentration of the dissolved organic 245 carbon present was determined using a TOC-analyzer (TOC-VCPH model, Shimadzu Scientific 246 Instruments, Columbia, MD, USA). A certified organic carbon control solution $(100 \mu \mathrm{g} / \mathrm{mL})$ 247 from SCP Science (Canada) was used to control of the accuracy of the results. Using a $\mathrm{H}_{2} \mathrm{~S}$ 248 detector (ToxiRAE Pro, San Jose, CA, USA), the gaseous hydrogen sulfide was measured at the 
249 outlet of the autotrophic denitrification system, at the inlet and above each reactor. As reactors

250 were buried, $\mathrm{H}_{2} \mathrm{~S}$ detector was introduced carefully above the soil in air compartment to perform

251 the measure.

252 The $\mathrm{pH}, \mathrm{ORP}$ and Dissolved Oxygen (DO) were measured using a Thermo Scientific

253 Orion STAR A322 conductivity portable meter. Before each series of $\mathrm{pH}$ measurements, a

$254 \mathrm{Ag} / \mathrm{AgCl}$ reference cell was calibrated using certified solution $(\mathrm{pH}=2.00,4.00$, and 7.00). The

255 ORP cell was verified before each series of measurements using a certified solution $(\mathrm{ORP}=$ $256470 \mathrm{mV})$.

257 All colorimetric methods used for the determination of sulfate, sulfide and Chemical oxygen 258 demand (COD) contents were performed using a UV-Vis spectrophotometer (Varian Cary® 50, 259 Varian Inc., Mississauga, ON, Canada). The sulfate analyses were performed using a modified 260 version of the method described by Bertolacini et al. (1957). A certified control solution (Multi261 element Ion Chromatography standard sol II in $\mathrm{H}_{2} \mathrm{O}$, Fluka, Sigma Aldrich, Canada) and an 262 ammonium sulfate solution (10 $000 \mu \mathrm{g}$ S/mL, Plasma Cal SCP Science, Canada) were used to 263 validate the accuracy of the measurements.

264 The dissolved sulfide analyses were also performed using a modified colorimetric method 265 according to Cline (1969). The chemical oxygen demand (COD) was determined according to 266 the method MA. 315 - COD 1.1 developed by the CEAEQ (MDDEFP, 2014). The calibration 267 curve was prepared from a potassium biphthalate stock solution (10 $\left.000 \mathrm{mg} \mathrm{O}_{2} / \mathrm{L}\right)$. Additionally, 268 a certified control solution (500 mg/L solution, calibration standard, RTC) was used to ensure the 269 quality of the results for each series of measurements. 


\section{RESULTS AND DISCUSSION}

\section{Pilot-scale experiments}

272 In the following study, the pilot-scale experiments were carried out on two different soil

273 samples (highly permeable and permeable). According to the particle size distribution (Ghorbel

274 et al., 2016), the mean particle size was estimated to be 378 and $269 \mu \mathrm{m}$, whereas the $\mathrm{D}_{10}$ values

275 were approximately 163 and $30 \mu \mathrm{m}$ for the highly permeable and permeable soils, respectively,

276 indicating that the latter contained higher amounts of small particles than the highly permeable

277 soil. Their hydraulic conductivities (Ks) were estimated at $0.028 \mathrm{~cm} / \mathrm{s}$ for the highly permeable

278 soil (100\% sand) and $0.0013 \mathrm{~cm} / \mathrm{s}$ for the permeable soil (85\% sand-15\% silt) (Gouvernement du

279 Québec, 2015). The experiments were conducted on the highly permeable soil (reactor R1) over

280 a single year, but the assays carried out on the permeable soil (reactor R2) were stopped after

28110 weeks of operation due to a clogging phenomenon. The factors that affected this clogging are

282 discussed in section 3.2.

283 The evolution of the various parameters studied for both reactors R1 and R2 are presented

284 in Figures 3 and 4. Table 2 shows the main characteristics of the feed solution (sampled from a 285 20-L-capacity storage tank of DW produced by the denitrification system). According to these 286 results, the ORP value was approximately $-40 \mathrm{mV}$, and the DO was estimated at $5.59 \mathrm{mg} / \mathrm{L}$.

287 These values were different from the ORP $(-300 \mathrm{mV})$ and DO $(<2 \mathrm{mg} / \mathrm{L})$ of the DW measured 288 directly in the denitrification system, which were very low (Ben-Khaled, 2016). The storage tank 289 was closed tightly and directly connected by pipes to the denitrified reactor. The DW from the 290 tank then passed through the top of the reactors, simulating the infiltration of DW through the 291 soil. 
Despite that no open-channel flow was used from the pump to the reactor and that only

293 closed-conduit flows were used, we have noticed that dissolved oxygen values increased

294 between the denitrified wastewater and those directly measured in the denitrification reactor.

295 Thus, the pipes ensure the aeration/oxygenation of the DW, which is very beneficial to avoid 296 sulfide generation. This can also be achieved by installing a drain field, as it is separated from 297 the wastewater distribution box by pipes (Service des eaux municipales, 2007). Sulfide 298 generation is highly dependent on the environmental conditions of the medium such as 299 temperature, $\mathrm{pH}$ and ORP. The evolution of temperature, $\mathrm{pH}, \mathrm{ORP}$ and DO of the feed solution 300 (DW) and of the effluents from reactors R1 and R2 during sampling are presented in Figure 3.

301 According to our results presented in Figure 3a, the temperature of the feed solution 302 (DW) and of the effluents from the reactors $\mathrm{R} 1$ and $\mathrm{R} 2 \mathrm{did}$ not reach below $4.6^{\circ} \mathrm{C}$ during the 303 winter (day 1 to 163 ), while the outside temperature reached $-20^{\circ} \mathrm{C}$ (Figure $3 \mathrm{a}$ ). The system was 304 underground and insulated by the soil, which prevented its freezing. During the summer (day 164 305 to 346), the highest temperature recorded for the effluents from reactors R1 and R2 was $19^{\circ} \mathrm{C}$. 306 According to Huan et al. (2013), low temperatures (lower than $7^{\circ} \mathrm{C}$ ) could highly affect and 307 delay the generation of gaseous and aqueous sulfides. However, an increase in the temperature 308 from 15 to $38^{\circ} \mathrm{C}$ lead to a $7 \%$ increase in the sulfide production, reaching its maximum at $30^{\circ} \mathrm{C}$ 309 (Huan et al., 2013). Indeed, in the present study, while the temperature gradually increased 310 during summer, a generation of aqueous and gaseous sulfides was recorded for the feed solution 311 with levels reaching $0.7 \mathrm{mg} / \mathrm{L}$ and $2.1 \mathrm{ppm}$, respectively.

312 Another important parameter has also been emphasized by many authors, who indicated 313 that a wide range of $\mathrm{pH}$ (4.5 and 9.2) seemed to be suitable for the generation of sulfide 314 (Benedetto et al., 2005; Cervantes et al., 2006; Gutierrez et al., 2009; Holland and Turekian, 
315 2010; Liu et al., 2015). According to Figure 3b, the pH of the feed solution (DW) and of the 316 effluent emerging from the highly permeable (reactor R1) and permeable (reactor R2) soils were 317 quite stable over the period of 365 days, with average values estimated at 6.68 for the feed 318 solution (DW), 7.00 for the effluent of reactor R1 and 7.30 for the effluent of reactor R2.

As shown in Figure 3, there was an obvious correlation between the $\mathrm{pH}$ and the 320 temperature. Actually, the higher temperatures of the summer caused an increase in molecular 321 vibration, which consequently led to a decrease of hydrogen bonds being formed, leading to an 322 increase of $\mathrm{H}^{+}$and a decrease in $\mathrm{pH}$ (Down and Lehr, 2005). However, the increase of $\mathrm{pH}$ values 323 for the effluents emerging from the reactors occurred due to the basic initial soil $\mathrm{pH}$ (8.40 and 3249.95 for the highly permeable and permeable soils, respectively). In addition, a slight increase of 325 the $\mathrm{pH}$ values can be due to the release of $\mathrm{CO}_{2}$ into the environment during microbial activity as 326 explained by Deepa and Krishnaveni. (2012) and Yuan et al. (2013). The latter has previously 327 been mentioned by Deepa and Krishnaveni (2012) for treated municipal wastewater (pH varying 328 between 7.4 and 8.0) after they passed through columns containing soil with an initial $\mathrm{pH}$ of 6.8 . 329 Moreover, such results have also been mentioned by Yuan et al. (2013) in a similar study with an 330 increase of $\mathrm{pH}$ values from the top (7.0-7.5) to the bottom of the soil column (8.5-9.0). However, $331 \mathrm{pH}$ values were still in the optimum range mentioned by Yeh (2000) for the production of sulfide 332 due to the reduction of sulfates by SRB.

The values of the ORP measured for the feed solution (DW) varied over the sampling 334 period. The ORP values measured downstream and into the denitrification reactor were 335 estimated at $-40 \mathrm{mV}$ and $-200 \mathrm{mV}$, respectively (Figure 3c). Indeed, a large variation in the ORP 336 values was observed at the beginning, with a significant decrease from the $64^{\text {th }}$ to the $191^{\text {st }}$ day, 337 and then an average value of $-94 \pm 45 \mathrm{mV}(\mathrm{n}=25)$ was attained. After this period, the ORP 
338 values of the feed solution (DW) increased, becoming positive with an average value of $339+101 \pm 42 \mathrm{mV}(\mathrm{n}=40)$. Moreover, it appeared that ORP is highly dependent on the $\mathrm{pH}$ value 340 (James, 2004). We can hypothesize that the decrease in $\mathrm{pH}$ (due to the increase in the 341 temperature), starting from the $200^{\text {th }}$ day, had a large impact on the ORP values, causing them to 342 increase. Despite the fluctuation observed at the beginning of the experiments, the ORP values of 343 both reactor R1 and reactor R2 effluents increased throughout the sampling period, with average 344 values of $+103 \pm 45(n=77)$ and $+75 \pm 15(n=6) m V$, respectively. Such ORP values indicate 345 an environment that is insufficiently reducing to generate sulfide formation (Annable, 2008). 346 Indeed, many authors have noted that ORP values of at least $-100 \mathrm{mV}$ are required for the SRB 347 activity (Abhilash et al., 2015; Huan et al., 2013). The same observation can be made for the 348 evolution of the DO of the feed solution (DW) over the sampling period. Indeed, the results 349 revealed an important fluctuation of the DO at the beginning of the experiments, followed by an 350 increase after the $66^{\text {th }}$ day. The average DO concentration was estimated at $4.9 \pm 1.4 \mathrm{mg} / \mathrm{L}$ ( $\mathrm{n}=$ 351 71) over the one-year sampling period. The concentration of the DO measured in both the 352 reactors $\mathrm{R} 1$ and $\mathrm{R} 2$ effluents were always higher at $7.8 \pm 1.5$ and $5.2 \pm 1.4 \mathrm{mg} / \mathrm{L}$, respectively, 353 than that of the feed solution $(4.9 \mathrm{mg} / \mathrm{L})$, indicating that the system aerated the water. According 354 to several studies, these conditions of high ORP values and DO concentrations prevent the 355 production of sulfide, as the SRB need very low ORP values and anaerobic conditions to grow 356 (Annable, 2008). In contrast to clay soils, sandy and sandy loam soils, mainly composed of large 357 and coarse grains, are well known for their good water percolation and gas exchange abilities. 358 These qualities reduce the development of anaerobic zones and, consequently, the reduction of 359 sulfates to sulfides by the SRB (Anderson and Halsey, 1980). 
Figure 4 presents the evolution of the concentration of Dissolved organic carbon (DOC),

361 sulfate and aqueous $\left(\mathrm{H}_{2} \mathrm{~S}_{(\mathrm{aq})}\right)$ and gaseous sulfide $\left(\mathrm{H}_{2} \mathrm{~S}_{(\mathrm{g})}\right)$. Despite the high hydraulic

362 conductivity of sandy soils, and the short residence time of the DW (Sandhu, 2013), a slight

363 purification was observed during the infiltration of the DW (DOC $=8.5 \pm 1.8 \mathrm{mg} / \mathrm{L} ; \mathrm{n}=77$ )

364 through the highly permeable soil (reactor R1), leading to further degradation of the remaining

365 organic matter $(\mathrm{DOC}=6.8 \pm 1.7 \mathrm{mg} / \mathrm{L} ; \mathrm{n}=90)$ (Figure 4a). Regarding the sandy loam soil, the

366 average value of the DOC $(9.5 \pm 3.2 \mathrm{mg} / \mathrm{L} ; \mathrm{n}=15)$ was higher than the values measured for the

367 feed solution ( $\mathrm{DOC}=8.5 \pm 1.8 \mathrm{mg} / \mathrm{L} ; \mathrm{n}=77$ ). This difference could be explained by the quantity

368 of the organic carbon initially present in this soil $(0.33 \%)$ in comparison to the sandy soil

$369(<0.05 \%)$ and by the release of organic matter from the silt present in a higher proportion in the

370 sandy loam soil. Moreover, the concentrations of the sulfates measured in the reactors R1 and R2

371 effluents, $146 \mathrm{mg} / \mathrm{L}$ and $161 \pm 39 \mathrm{mg} / \mathrm{L}(\mathrm{n}=15)$, respectively, were similar to that of the feed

372 solution $(137 \pm 43 \mathrm{mg} / \mathrm{L} ; \mathrm{n}=81)$, indicating that the SRB did not reduce sulfates to sulfide in

373 both types of soils (Figure 4b).

374 Denitrified wastewater was measured at the output of the denitrifrication process before

375 reaching the storage tank from which we supplied the reactors. Over the one-year sampling

376 period, the highest level of $\mathrm{H}_{2} \mathrm{~S}(\mathrm{~g})$ recorded was around $14 \mathrm{ppm}$ for the output directly of the

377 denitrification reactor and at $2.1 \mathrm{ppm}$ for the feeding solution (DW pumped from the storage

378 tank) (Figure 4d). This sulfide concentration (14 ppm) produces an offensive and foul odor

379 (Chou, 2003). According to the Canadian Centre for Occupational Health and Safety (2005), a

380 concentration of $100 \mathrm{ppm}$ causes severe symptoms such as respiratory tract, eye irritation and

381 loss of smell. A range of concentrations varying between 500 and 1000 ppm leads to collapse

382 and even death. The concentration of gaseous hydrogen sulfide in reactors R1 and R2 did not 
exceed $0.5 \mathrm{ppm}$, indicating that no hydrogen sulfide was produced during the infiltration of DW

384 through both the highly permeable and permeable soils. This observation was confirmed by the 385 evolution of the sulfate concentrations over the sampling period, which remained similar to the 386 initial concentration of the feed solution.

387 Although the $\mathrm{COD} / \mathrm{SO}_{4}{ }^{2-}$ ratio occasionally reached 2.3 (on the $308^{\text {th }}$ day), which is higher 388 than the minimal ratio of 0.67 indicated in other studies for the production of $\mathrm{H}_{2} \mathrm{~S}$ (Biswas and 389 Tapas, 2012; Dar et al., 2008; Velasco et al., 2008), no sulfide generation occurred. 390 Theoretically, there was enough organic matter in the DW (up to a ratio of 2.3) to promote the 391 activity of the SRB and therefore generate sulfide. However, the two soils used during these 392 experiments (highly permeable and permeable) enabled increases both of the DO (7.9 and $3935.3 \mathrm{mg} / \mathrm{L})$ and the ORP values $(+103$ and $+75 \mathrm{mV})$, which are critical parameters for the activity 394 of the SRB and therefore the production of sulfide.

There are some differences between natural soils and the artificially-created soils used in 396 the present study that can affect the observation made related to the generation of sulfide during 397 the infiltration of denitrified wastewater through the soils. Natural soils have a high spatial 398 heterogeneity with respect to their physical, chemical and biological properties. Natural soils are made 399 of solid matter, water and air. The solid matter could be composed of organic or mineral material. The 400 bulk density ranges from values lower than $0.5 \mathrm{~g} / \mathrm{cm}^{3}$ in organic soils to $1.8 \mathrm{~g} / \mathrm{cm}^{3}$ in mineral soils 401 (Reddy and DeLaune, 2008). Depending on the season, these soils could be under drained or flooded 402 conditions, which highly affect air-filled pore space of soil and thereby the soil aeration by oxygen 403 diffusion. This latter governs most of the biogeochemical reactions. Thus, from a biological point of view, 404 facultative and obligate anaerobes bacteria predominate when the oxygen is depleted, generally in poorly 405 drained soils with fine-textured soils. The oxidized compounds are reduced through chemical and 
biological processes, whereas aerobic bacteria predominate in well-drained, coarser-textured soils and

407 oxidize the reduced forms present in soils. Moreover, compared to the artificial soil columns

408 (mineral soil), oxygen governs most of the biogeochemical reactions. It is important to mention

409 that the oxygen in soil is needed for microbial respiration but also to plant root respiration

410 through diffusion and mass flow. Moreover, the application of animal waste, compost, sewage

411 sludge or fertilizer can also result in oxygen depletion in the soil (Reddy and DeLaune, 2008).

\section{Clogging phenomenon}

The accumulation of treated wastewater at the surface of the reactor (persistent ponding)

414 was first detected in the sandy loam soil after 37 days of continuous flow rate infiltration. Once

415 the overflow occurred, wastewater feeding was stopped, and the water level was monitored at a

416 reference point. Figure 5 shows the ponding depth (level of the liquid accumulated on the

417 surface) for a period of 35 days. According to the results, over time, the clogging of the system

418 led to a decrease in the infiltration rate. The numerous reasons responsible for this clogging

419 phenomenon will be explored below. During the first 15 days after ponding, the system was fed

420 with $17.2 \mathrm{~L}$ of DW per day and then stopped; the infiltration rate of the wastewater was

421 followed. According to the results, the infiltration velocity of the DW into the soil was estimated

422 to be approximately $1.6 \mathrm{~cm} /$ day from day 0 to day 15 . Thereafter, the pump was switched on,

423 and the permeable soil reactor was fed with the DW for another 7 days. However, the ponding

424 phenomenon persisted, and the infiltration velocity decreased, leading to an average value of

$4250.5 \mathrm{~cm} /$ day that tended to reach a steady state. As mentioned by Lowe and Siegrist (2008), this

426 state is called the "end state". This state occurred in the reactor R2 (sandy loam soil) after 9

427 weeks of infiltration, while the $1^{\text {st }}$ reactor R1 (sandy soil) never reached the end state. When the

428 reactor R2 reached this end state, the feeding of this reactor was completely stopped, and the soil 
429 profile was analyzed to understand why the clogging phenomenon occurred. For the same soils, 430 no rapid and severe clogging had occurred during previous laboratory-scale experiments carried 431 out by Ghorbel et al. (2016). These differences between laboratory and pilot scales might be due 432 to the higher loading rate that can lead to a decrease in the infiltrative capacity and a loss of 433 permeability, as discussed by Hargett et al. (1981). Several hypotheses were explored to explain 434 the clogging phenomenon, which occurred in the second reactor with the permeable soil at pilot 435 scale. The reactor was fully dismantled and soil cores were sampled as a function of depth in 436 several separate sections of about $1 \mathrm{~cm}$ each. Thus, tests were conducted on thin soil sections 437 collected at 17 different depths. The particle size distribution, moisture and organic carbon 438 contents of these thin sections were measured to identify the chemical or physical changes. The 439 results are presented in Figure 6.

440 First, the potential migration of the fine particles through the sandy particles (thereby 441 limiting the infiltration of the DW) was explored. Figure 6a shows the particle size distribution 442 of the 17 different soil sections of the second reactor as a function of the particle diameter. 443 Regardless of the depth of the sections, the results showed a good superposition of the particle 444 size distribution curves, indicating that no fine particles had migrated to the gravel at the bottom 445 of the reactor. Therefore, it was concluded that the observed clogging phenomenon was not due 446 to the migration of fine particles creating an impermeable layer.

$447 \quad$ Figure $6 \mathrm{~b}$ presents the moisture content measured for the 17 different thin soil sections 448 collected. Regardless of the depth of the sections, a soil moisture content of $12.5 \pm 1.1 \%(n=17)$ 449 was measured for almost all soil samples. Unfortunately, these results did not allow for the 450 detection of variations in soil moisture contents in the soil profile. 
Next, further investigations were carried out to explain the clogging effect. Lowe and

452 Siegrist (2008) assumed that clogging is a highly time-dependent process during which

453 wastewater pollutants such as humic matter fills the pore of the soil. Other authors found that

454 biological activities, especially under aerobic conditions, lead to the formation of by-products

455 such as an extra polymeric substance (EPS), which cause the clogging phenomenon (McKinley

456 and Siegrist, 2011; Winstanley and Fowler, 2013). Additionally, many studies have shown that

457 the presence of organic carbon in the infiltration surface causes substantial soil clogging (Siegrist

458 and Thresher, 1985; Winstanley and Fowler, 2013). Figure 7a shows a thin brown layer of

459 approximately $5 \mathrm{~mm}$, which formed on the infiltration surface of the reactor R2. This thin layer

460 had a different color than the rest of the soil profile, which was similar to the color of the initial

461 soil. This layer, also referred to as a biomat, is generally due to the deposition of organic matter.

462 It usually influences the infiltration capacity of a soil regardless of its initial permeability (White

463 and West, 2003). The organic carbon analysis, performed on the different soil samples collected,

464 showed that the quantities of organic carbon were similar across all of the 17 soil samples (less

465 than 2.0\%). However, the biomat layer showed a high enrichment of organic matter with a 466 quantity of organic carbon reaching 7.5\% (Figure 6c). Therefore, the biomat highly influenced

467 the infiltration of treated wastewater through the soil by clogging the surface.

468 During the complete dismantling of the second reactor (permeable soil), a red and 469 gelatinous layer was found at the bottom, which prevented the complete removal of the DW from

470 the reactor (Figure 7b). A complete analysis of this sludge showed that its ferric content of $471 \quad 112 \mathrm{~g} / \mathrm{kg}$ was 14 times higher than the $7.70 \mathrm{~g} / \mathrm{kg}$ of the initial soil sample. As described by Ford 472 (1985), iron sludge can play an important role in the clogging phenomenon. Moreover, Smart 473 and Herbertson (1992) correctly described this red-brown gelatinous material as iron ochre. 
474 Ferrous iron compounds were oxidized deep in the soil to insoluble ferric oxide $\left(\mathrm{Fe}_{2} \mathrm{O}_{3}\right)$,

475 blocking tank adapter and causing the clogging phenomenon (Smart and Herbertson, 1992).

476 According to Lindbo et al. (2014), the biological oxidation of iron requires free oxygen, a source

477 of organic matter and iron and a temperature above $5^{\circ} \mathrm{C}$. Other key factors for soil saturation and

478 iron redox reactions include retention time and soil depth (Lindbo, 2014). The presence of

479 stagnant water favors anaerobic conditions. Thus, the ferrous iron present in soil migrates to the

480 ponding-water using the iron-reducing bacteria (Ford, 1985), followed by their oxidation in the

481 interface between the anaerobic and aerobic zones, forming a layer. This process also depends on

482 the chemical species present in the submerged soil and on the second law of thermodynamics

483 (change in Gibbs free energy or $\Delta \mathrm{G}^{\circ}$ ). Following a precise order of preference, bacteria first use

484 oxygen $\left(\mathrm{O}_{2}\right)$ to oxidize the organic matter, followed by nitrates $\left(\mathrm{NO}_{3}{ }^{-}\right)$, oxide of manganese

$485\left(\mathrm{MnO}_{2}\right)$, oxide of iron $\left(\mathrm{Fe}_{2} \mathrm{O}_{3}\right)$, sulfate $\left(\mathrm{SO}_{4}{ }^{2-}\right)$ and, finally, $\mathrm{CO}_{2}$ for methane fermentation (Reddy

486 and DeLaune, 2008). Because iron ions precede sulfates, the presence of ferrous ions limits the

487 formation of sulfide ions (Baveye et al., 1998).

Therefore, unlike for the small scale (Ghorbel et al., 2016), where much lower sulfide

489 occurred ( $<0.15 \mathrm{ppm}$ and $<0.2 \mathrm{mg} / \mathrm{L}$ for gaseous and aqueous sulfide, respectively), a slight

490 emission of $\mathrm{H}_{2} \mathrm{~S}$ was observed in the feed solution, while temperature increased. This emission

491 of $\mathrm{H}_{2} \mathrm{~S}$ seemed proportionally related to changes in temperature and $\mathrm{pH}$. Although the increase of

492 both temperature and $\mathrm{pH}$ is slight and restricted to the feed solution, this was responsible of the

493 increase of the solubility of organic compounds which were more available for the

494 microorganisms, leading to an increase of the speed of both biological reactions and conversion. 
497 appeared on the infiltrative surface followed by the formation of iron ochre at the bottom of the 498 reactor both causing the clogging phenomenon. Additionally, the biomat itself indirectly led to 499 the formation of the iron ochre. Actually, the appearance of the biomat layer first led to flood the 500 soil which became depleted in oxygen. This state allowed the ferric ions present in the soil to 501 migrate in water by means of iron-reducing bacteria (Ford, 1985) followed by the oxidation of 502 the latter in contact with air (bottom of reactor). This resulted in the formation of iron ochre at 503 the bottom of the reactor R2. Thus, these two phenomena are responsible for the phenomenon of 504 clogging observed in the reactor R2. Moreover, the reduction of ferrous ion $505\left(\Delta G^{0}=-115.0 \mathrm{~kJ} / \mathrm{mol}\right)$ avoided sulfide generation in the same time as the sulfates reduction $506\left(\Delta \mathrm{G}^{0}=-104.7 \mathrm{~kJ} / \mathrm{mol}\right)$ for the permeable soil. High hydraulic loading rate could also be one of 507 the reasons that can be responsible to the clogging phenomenon observed for the reactor R2. 508 Actually, the high hydraulic loading rate induces the presence of high organic matter content to 509 the reactor, which may have accelerated the biomat formation in the infiltration surface.

510 Finally, we could assume that no important sulfide was generated downstream the 511 autotrophic-denitrification system during the infiltration of DW through highly permeable soil 512 over one year sampling. As mentioned by Sierra et al. (2007), we can also confirm that a further 513 treatment step (cascade aeration with a sand field) is important for a safe infiltration of the 514 denitrified soil, as long as the organic matter is present at a low amount. Indeed, a wastewater 515 with low $\mathrm{BOD}_{5}$ will ensure the oxygen flow to the system (Erickson, 2000). 


\section{CONCLUSION}

This study focused on the behavior of artificially-created soils infiltrated by treated

518 wastewater containing large quantities of sulfates from a decentralized domestic wastewater

519 treatment process based on autotrophic sulfur denitrification. The results indicated that the

520 wastewater treated by the autotrophic sulfur-limestone process did not lead to the production of

521 problematic amounts of aqueous or gaseous sulfide $\left(\mathrm{H}_{2} \mathrm{~S}_{(\mathrm{aq})}<0.1 \mathrm{mg} / \mathrm{L}\right.$ and $\left.\mathrm{H}_{2} \mathrm{~S}_{(\mathrm{g})}<0.5 \mathrm{ppm}\right)$ in

522 the outflow. The concentration of sulfide in the feeding solution (denitrified wastewater) did not

523 exceed $0.7 \mathrm{mg} / \mathrm{L}$ of aqueous sulfide and $2.1 \mathrm{ppm}$ of gaseous sulfide. This observation might be

524 explained by the fact that the DO and ORP values did not reach target values conducive to the

525 SRB activity. Moreover, because this process was installed downstream of a secondary process,

526 there was less easily biodegradable residual organic carbon available for the SRB.

Another observation was the occurrence of a clogging phenomenon in the permeable soil.

528 Many hypotheses were proposed to explain the loss of permeability, which involved the

529 formation of a biomat layer on the infiltration surface, and the formation of iron ochre in the

530 sandy loam soil. To avoid these problems during the operation of a functioning full-scale

531 wastewater infiltration system, a further treatment step (cascade aeration) with a sand field is

532 important for a safe infiltration of the denitrified wastewater.

$533 \quad$ Further experiments should be performed with different hydraulic loading rates including

534 typical hydraulic loading rates $\left(65 \mathrm{~L} / \mathrm{m}^{2} /\right.$ day for the highly permeable soil and at $35 \mathrm{~L} / \mathrm{m}^{2} /$ day for 535 the permeable soil) and the same hydraulic loading rates as those used in this study 536 (130 L/m²/day for the highly permeable soil and at $70 \mathrm{~L} / \mathrm{m}^{2} /$ day for the permeable soil) to further

537 understand the formation of the clogging phenomenon. Moreover, denitrified wastewater 538 infiltration into a real soil (with higher organic matter and the presence of plants) would be very 
539 interesting to have a better comprehension of the mechanisms responsible of the potential sulfide

540 generation.

\section{ACKNOWLEDGMENTS}

542 The writers are grateful for the financial and technical support of Premier Tech Aqua, the Natural

543 Sciences and Engineering Research Council of Canada and Research Funds of Quebec Nature

544 and Technology. Mrs. Ginette Bélanger and Mrs. Myriam Chartier are acknowledged for their

545 significant contribution. Sincere thanks are extended to Mrs. Jihen Ben Khaled and Mr. André

546 Ouellet 


\section{REFERENCES}

Abhilash, Pandey, B.D., Natarajan, K.A. (2015). "Microbiology for minerals, metals, materials and the environment". CRC Press, Boca Raton, NY, USA, 608 p.

Anderson, J.L., Halsey, C.F. (1980). "Evaluating soil texture for a house site". Agricultural Extension Service, University of Minnesota, Minneapolis, MN, USA.

553

Annable, M.D., Teodorescu, M., Hlavinek, P., Diels, L. (2008). "Methods and techniques for cleaning-up contaminated sites". Springer, Dordrecht, Netherlands, 196 p.

Barton, L., Hamilton, W.A. (2007). "Sulphate-reducing bacteria : environmental and engineered systems". Cambridge University Press, Cambridge, NY, USA, 552 p.

Baveye, P., Vandevivere, P., Hoyle, B.L., DeLeo, P.C., de Lozada, D.S. (1998). "Environmental Impact and Mechanisms of the Biological Clogging of Saturated Soils and Aquifer Materials". Crit.Rev. Environ. Sci. Technol. 28, 123-191.

Beauchamp, R.O., Bus, J.S., Popp, J.A., Boreiko, C.J., Andjelkovich, D.A., Leber, P. (1984). "A Critical Review of the Literature on Hydrogen Sulfide Toxicity." Crit.Rev. Toxicol. 13:25-97.

Ben-Khaled J. (2016). "Couplage de la dénitrification autotrophe sur soufre aux systèmes de traitement biologique des eaux usées domestiques applicables au secteur de l'assainissement décentralisé". Thesis report, INRS, University of Quebec, Quebec, QC, Canada, $199 \mathrm{p}$.

Benedetto, J.S., de Almeida, S.K., Gomes, H.A., Vazoller, R.F., Ladeira, A.C.Q. (2005). "Monitoring of sulfate-reducing bacteria in acid water from uranium mines". Minerals Eng. 18, 1341-1343.

Bertolacini, R.J., Barney, J.E., (1957). "Colorimetric determination of sulfate with barium chloranilate." Anal. Chem. American Chem. Soc. 29, 281-283. 
572 Biswas, T. (2012). "Effect of Linoleic Acid and COD/SO42- Ratio on Anaerobic Sulphate 573 Reduction in Semi-Continuous Reactors". Thesis report, University of Windsor, Windsor, ON, Canada, 119 p.

575 Buchanan, J.R. (2014). "3.13 - Decentralized Wastewater Treatment". In: Ahuja, S. (Ed.), Comprehensive Water Quality and Purification. Elsevier, Calabash, NC, USA, 1536 p.

Canada. (2014-2015). "Rapport de données quotidiennes Rivière-du-Loup".

Chou, C.H.S.J. (2003). "Hydrogen Sulfide". World Health Organization, Geneva, Swiss.

Christianson, L., Lepine, C., Tsukuda, S., Saito, K., Summerfelt, S. (2015). "Nitrate removal effectiveness of fluidized sulfur-based autotrophic denitrification biofilters for recirculating aquaculture systems". Aquacultural Eng. 68, 10-18.

Cline, J.D., (1969). "Spectrophotometric determination of hydrogen sulfide in natural waters." Limnol. Oceanogr. 13, 454-458.

Dar, S.A., Kleerebezem, R., Stams, A.J.M., Kuenen, J.G., Muyzer, G. (2008). "Competition and coexistence of sulfate-reducing bacteria, acetogens and methanogens in a lab-scale anaerobic bioreactor as affected by changing substrate to sulfate ratio". Appl. Microbiol. Biotechnol.78, 1045-1055.

Deepa, K., Krishnaveni, M., (2012). "Water quality performance of soil aquifer treatment (SAT) using municipal treated wastewater of Chennai city, India." J. Environ. Hydrol. 20, 1-9.

Down, R.D., Lehr, J.H. (2005). "Environmental instrumentation and analysis handbook". WileyInterscience, Hoboken, NJ, USA.

Erickson, T.E.J. (2000). "Soil Oxygen Delivery to Wastewater Infiltration Surfaces". Conference Proceedings National Onsite Wastewater Recycle Association, USA, pp. 91-96.

Ford, H.W. (1985). "Iron ochre and related sludge deposits in subsurface drain lines". Florida of Florida, Gainesville, FL, USA.

Ghorbel, L., Coudert, L., Gilbert, Y., Mercier, G., Blais, J.F. (2016). "Assessment of sulfide production risk in soil during the infiltration of domestic wastewater treated by a sulfurutilizing denitrification process". Environ. Sci. Pollut. Res., 1-13. 
600 Glass, D.C. (1990). "A review of the health effects of hydrogen sulphide explosure." Annals of 601 Occupational Hygiene 34: 323-327.

602 Gouvernement du Québec (2015). "Règlement sur l'évacuation et le traitement des eaux usées 603 des résidences isolées", Government of Quebec, Québec, QC, Canada.

604 Gutierrez, O., Park, D., Sharma, K.R., Yuan, Z. (2009). "Effects of long-term pH elevation on 605 the sulfate-reducing and methanogenic activities of anaerobic sewer biofilms". Water 606 Res. 43, 2549-2557.

607 Hargett, D.L., Tyler, E.J., Siegrist, R.L., Project, S.S.W.M. (1981). "Soil infiltration capacity as 608 affected by septic tank effluent application strategies. Small Scale Waste Management Project". University of Wisconsin, Madison, Wi, USA, 13 p.

James, C.N., Copeland, R., Lytle, D.A. (2004). "Relationships between oxidation-reduction potential, oxidant, and pH in drinking water". In: US EPA (Ed.), AWWA WATER Quality Technology Conference, San Antonio, TX, USA.

Kimura, K., Nakamura, M., Watanabe, Y. (2002). "Nitrate removal by a combination of elemental sulfur-based denitrification and membrane filtration". Water Res. 36, 17581766.

Lens, P.N.L., Hulshoff Pol, L. (2004). Environmental technologies to treat sulfur pollution : principles and engineering. IWA Publishing, London, United Kingdom, 550 p.

623 Lindbo, D.L., Amoozegar, A., Anderson, Vick Jr., D.R.L., Vepraskas, M.J. (2014). "Understanding and Interpreting Oxyaquic Conditions, Innovation in Soil-Based Onsite Wastewater Treatment". Soil Science Society of America, Albuquerque, NM, USA. 
Liu, Z.H., Maszenan, A.M., Liu, Y., Ng, W.J. (2015). "A brief review on possible approaches towards controlling sulfate-reducing bacteria (SRB) in wastewater treatment systems". Desalin. Water Treat. 53, 2799-2807.

Longpré-Girard, M., Martel, R., Robert, T., Lefebvre, R., Lauzon, J.M. (2016). "2D sandbox experiments of surfactant foams for mobility control and enhanced LNAPL recovery in layered soils." J. Contam. Hydrol. 193, 63-73.

Lowe, K., Siegrist, R. (2008). "Controlled Field Experiment for Performance Evaluation of Septic Tank Effluent Treatment during Soil Infiltration". J. Environ. Eng. 134, 93-101.

Martel, R., Gélinas, P.J. (1996). " Surfactant Solutions Developed for NAPL Recovery in Contaminated Aquifers." Groundwater 34, 143-154.

McKinley, J.W., Siegrist, R.L. (2011). "Soil Clogging Genesis in Soil Treatment Units Used for Onsite Wastewater Reclamation: A Review". Crit. Rev. Environ. Sci. Technol. 41, 2186-2209.

MDDEFP (2014). "Détermination de la demande chimique en oxygène : Méthode de reflux en système fermé suivi d'un dosage par colorimétrie avec le bichromate de potassium, MA. 315 - DCO 1.1, Rév. 3". Ministère du Développement Durable, de l'Environnement, de la Faune et des Parcs, Quebec, QC, Canada, 11 p.

MDDEFP (2013). "Étude d'impact économique du projet de règlement modifiant le règlement sur l'évacuation et le traitement des eaux usées des résidences isolées". Ministère du Développement Durable, de l'Environnement, de la Faune et des Parcs, Quebec, QC, Canada, $15 \mathrm{p}$.

MDDELCC (2015). "Règlement sur l'évacuation et le traitement des eaux usées des résidences isolées". Government of Quebec, Quebec, QC, Canada.

Musy, A., Soutter, M. (1991). "Physique du sol". Presses polytechniques et universitaires romandes, Lavoisier, Lausanne, Paris, France.

Nielsen, P.H., Raunkjær, K., Hvitved-Jacobsen, T. (1998). "Sulfide production and wastewater quality in pressure mains". Water Sci. Technol. 37, 97-104. 
653 Partlo, L.A., Sainsbury, R.S., Roth, S.H. (2001). "Effects of Repeated Hydrogen Sulphide (H2S)

654 Exposure on Learning and Memory in the Adult Rat." NeuroToxicology 22:177-189.

655 PTA (2015) "PremierTech", Rivière du Loup, QC, Canada. Compagny website available at the

656 following address: http://www.premiertechaqua.com/assainissement-traitement-eaux-usees.

657 Consulted on 17-03-2015.

658 Reddy, K.R., DeLaune, R.D. (2008). "Biogeochemistry of wetlands : science and applications".

659 CRC Press, Boca Raton, NY, USA, 800 p.

660 Reiffenstein, R.J., Hulbert, W.C., Roth, S.H. (1992). "Toxicology of Hydrogen Sulfide." Annual 661 Rev. Pharmacol. Toxicol. 32:109-134.

662 Sandhu, C., Fichtner, T., Hasan, I., Gräber, P.W. (2013). "Predicting the Impact of Treated 663 Wastewater Infiltration on Groundwater Recharge by Simulating Reactive Transport in 664 the Unsaturated Zone". HYDRUB Workshop, 10 p.

665 Service des eaux municipales (2007). "Traitement des eaux usées des résidences isolées guide technique. Service des eaux municipales". Direction des politiques de l'eau, Ministère du développement durable, de l'environnement et des parcs, Québec, QC, Canada.

Siegrist, R.L., Thresher, J.E. (1985). "Microanalysis of Wastewater Amended Vadose Zone Soils". The National Water Well Conference, p. 9.

Simard, M., Masson, S., Mercier, G., Benmoussa, H., Blais, J., Coudert, L. (2015). "Autotrophic Denitrification Using Elemental Sulfur to Remove Nitrate from Saline Aquarium Waters". J. Environ. Eng.141, 04015037.

676 Smart, P., Herbertson, J.G. (1992). "Drainage design". Blackie, Glasgow, United Kingdom.

677 Soares, M.I.M. (2002). "Denitrification of groundwater with elemental sulfur". Water Res. 36, 1392-1395.

679 Soil Science Society of America (2014). "Innovation in soil-based onsite wastewater treatment". 680 Conference Proceedings; April 7 - 8, 2014, Albuquerque, NM, USA, 325 p. 
Statistics Canada (2011). Households and the Environment. Statistics Canada and Ministry of Industry, Ottawa, ON, Canada, $227 \mathrm{p}$.

Van Der Hoek, J.P., Kappelhof, J.W.N.M., Hijnen, W.A.M. (1992). "Biological Nitrate Removal from Ground Water by Sulfur/Limestone Denitrification". J. Chem. Technol. Biotechnol. 54, 197-200

686

Velasco, A., Ramírez, M., Volke-Sepúlveda, T., González-Sánchez, A., Revah, S. (2008). "Evaluation of feed $\mathrm{COD} /$ sulfate ratio as a control criterion for the biological hydrogen sulfide production and lead precipitation". J. Hazard. Mater. 151, 407-413.

White, K.D., West, L.T. (2003). "In-Ground Dispersal of Wastewater Effluent: The Science of Getting Water into the Ground". Small Flows Quarterly 4, 28-35.

Winstanley, H.F., Fowler, A.C. (2013). "Biomat Development in Soil Treatment Units for Onsite Wastewater Treatment". Bull .Math. Biol. 75, 1985-2001.

Xu, Y., Chen, N., Feng, C., Hao, C., Peng, T. (2016). "Sulfur-based autotrophic denitrification with eggshell for nitrate-contaminated synthetic groundwater treatment". Environ. Technol., 1-10.

Yeh, E. (2000). "Raw sludge as substrate for sulphate-reducing bacteria". Thesis report, University of Toronto, Toronto, ON, Canada, $146 \mathrm{p}$.

Yuan, H., Nie, J., Zhu, N., Miao, C., Lu, N. (2013). "Effect of temperature on the wastewater treatment of a novel anti-clogging soil infiltration system". Ecological Eng. 57, 375379.

Zhang, J.S.T.C., 1998. "Septic tank effluent denitrification with sulfur/limestone processes". Conference on Hazardous Waste Research, Utah, UT, USA, p. 15.

Zhang, T.C., Shan, J. (1999). "In Situ Septic Tank Effluent Denitrification Using a SulfurLimestone Process". Water Environ. Res. 71, 1283-1291.

Zhou, W., Sun, Y., Wu, B., Zhang, Y., Huang, M., Miyanaga, T., Zhang, Z. (2011). "Autotrophic denitrification for nitrate and nitrite removal using sulfur-limestone". J. Environ. Sci. 23, 1761-1769. 
$710 \quad$ FIG. 1

711

712 FIG. 2

713

714

715

716

717

718

719

720

721

722 FIG. 5

723

724 FIG. 6

725

726

727

Schematic representation of the septic system used (modified from PTA, 2015)

Experimental design used for pilot scale experiments : a. Schematic representation of the composition of the different reactors, b. Photography of the reactors (by Leila Ghorbel) and c. Photography of the denitrified wastewater distribution system (by Leila Ghorbel)

FIG. 3 Evolution of the temperature (a.), pH (b.), ORP (c.) and Dissolved Oxygen (d.) during the infiltration of denitrified wastewater (feeding solution) through highly permeable soil (reactor R1) and permeable soil (reactor R2)

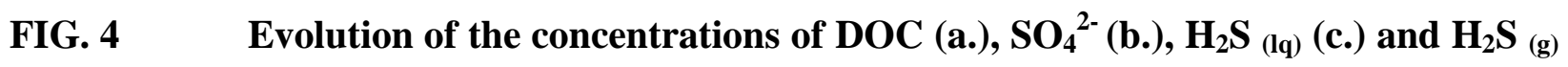
(d.) during denitrified wastewater (feeding solution) infiltration through highly permeable soil (reactor R1) and permeable soil (reactor R2)

Infiltration rate of treated wastewater through the sandy loam soil (R2) during the clogging period

Investigation of soil sections to explain the clogging phenomenon : Particle size distribution (a.), Moisture content (b.) and Organic carbon content (c.)

FIG. 7 Formation of biomat layer (a.) and iron ochre (b.), responsible of clogging phenomenon (Photography by Leila Ghorbel) 


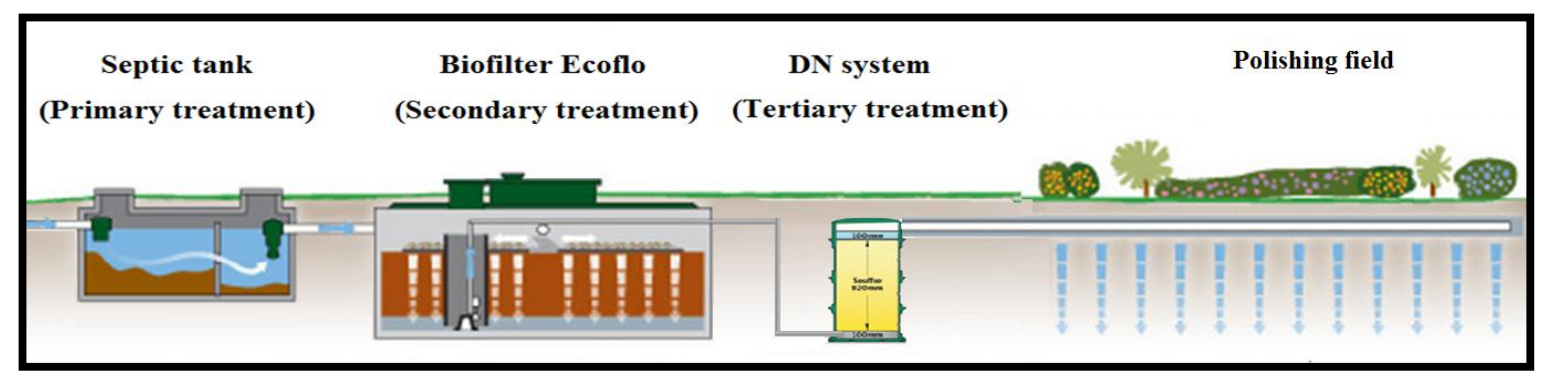

729

$730 \quad$ Fig. 1 


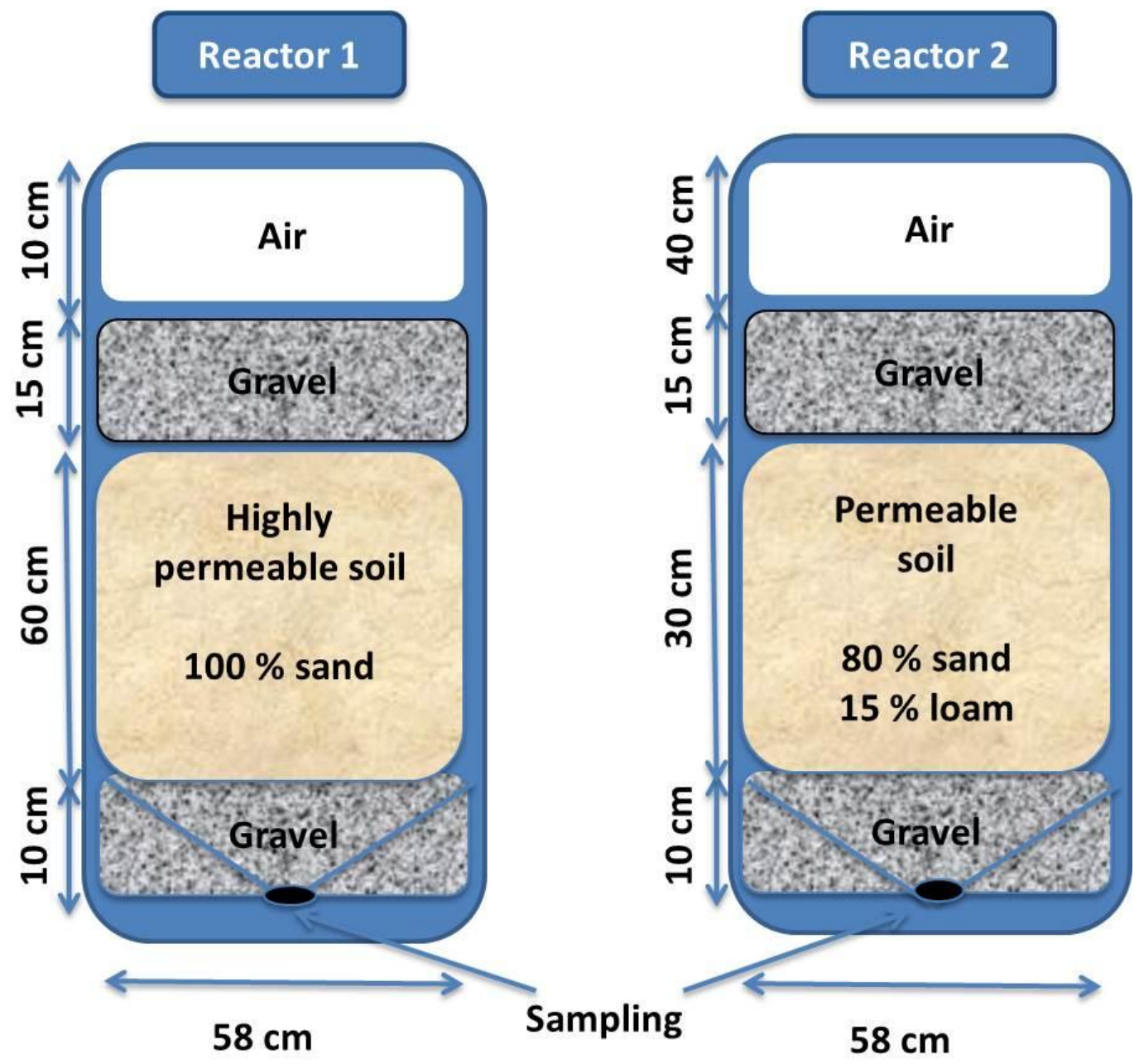

a. 

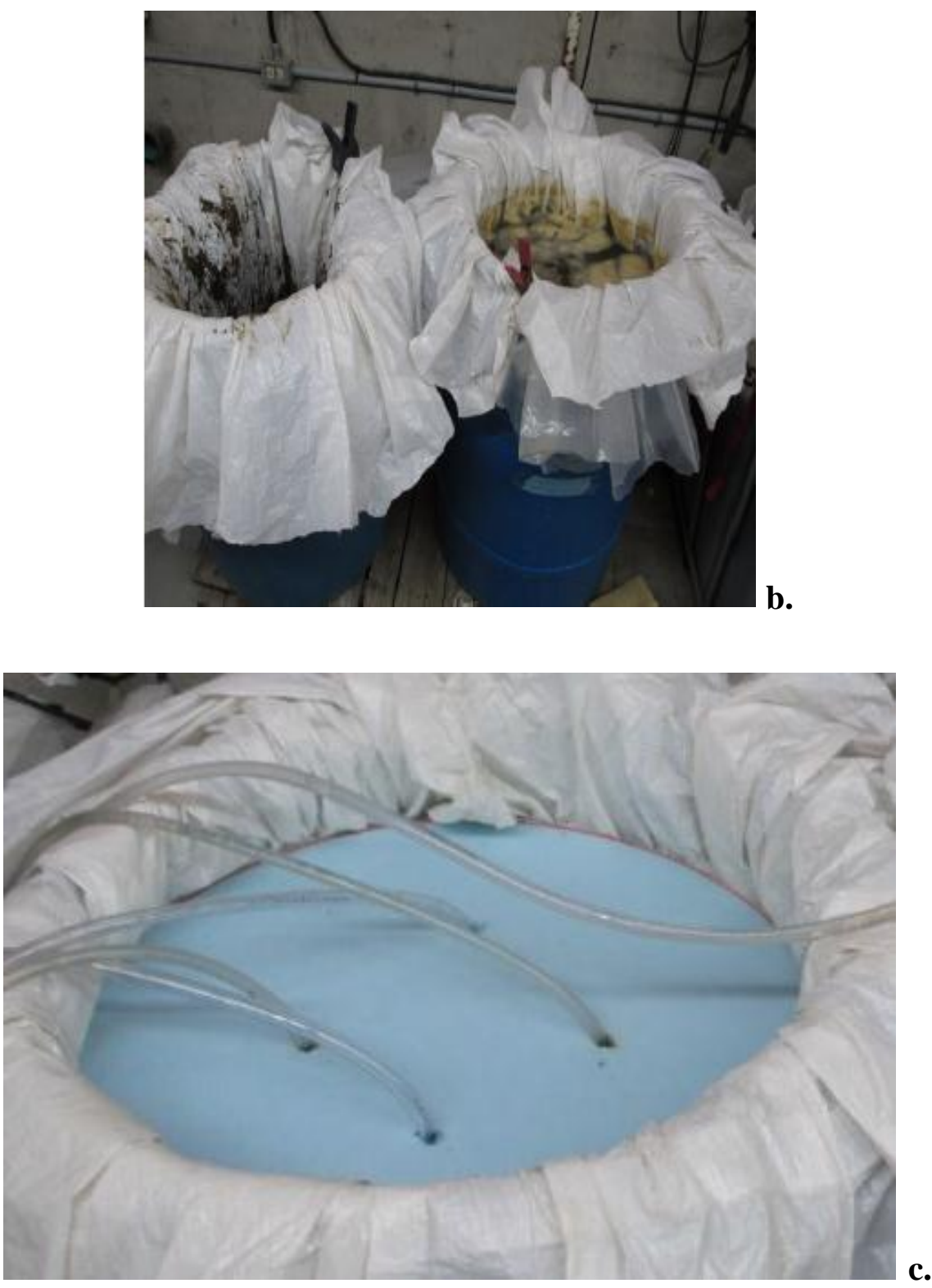

Fig. 2. 


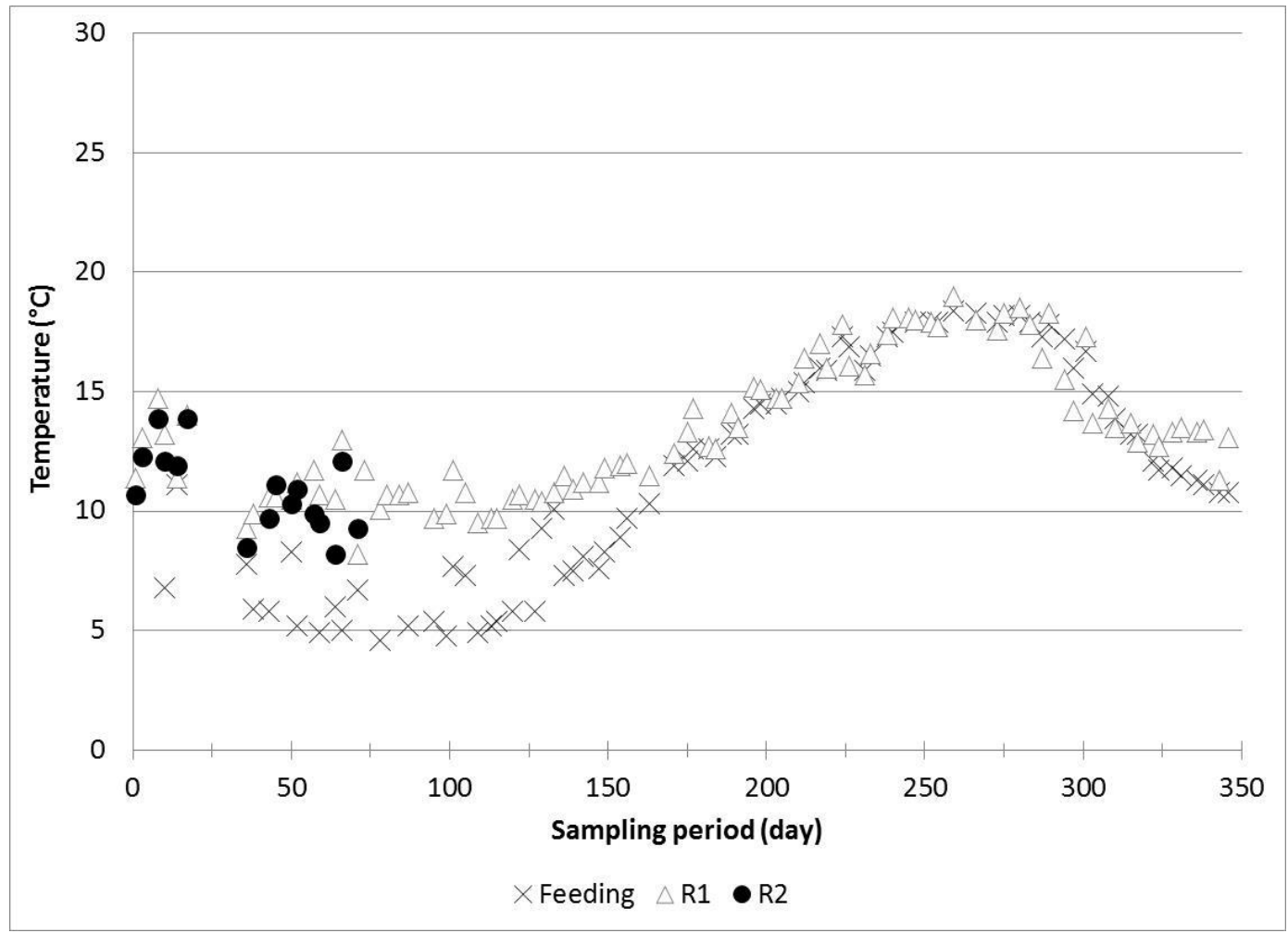

a.

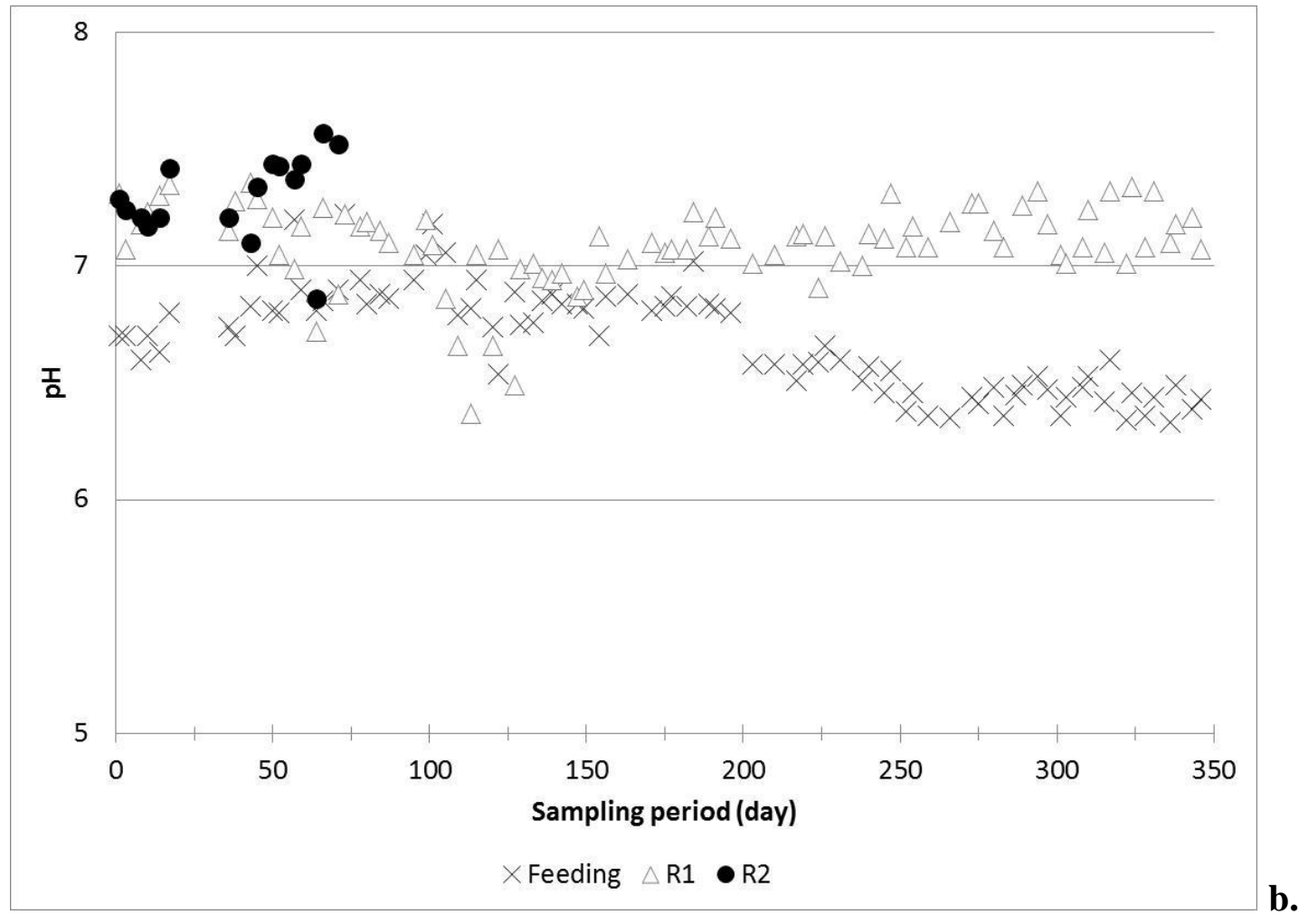



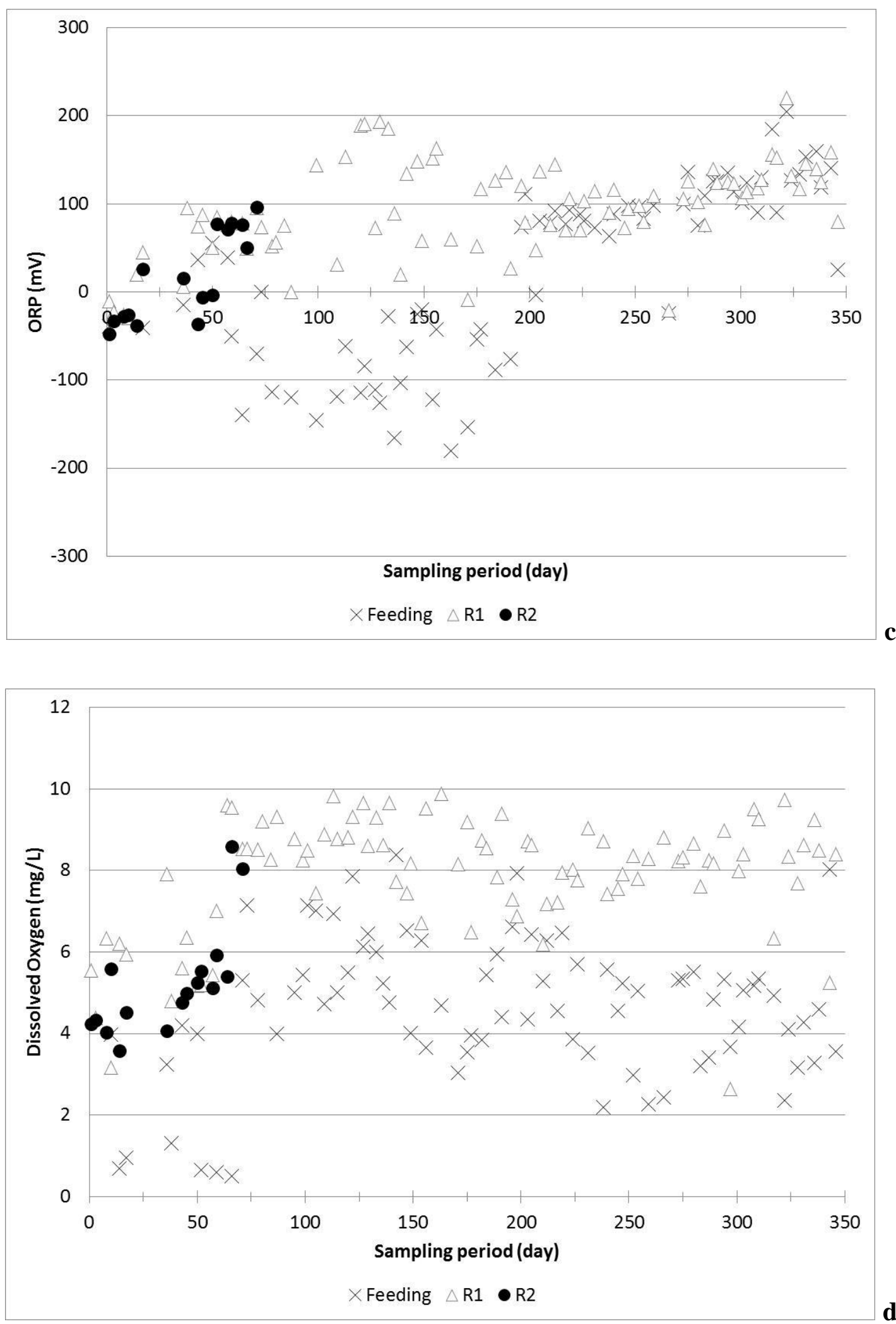

Fig. 3. 

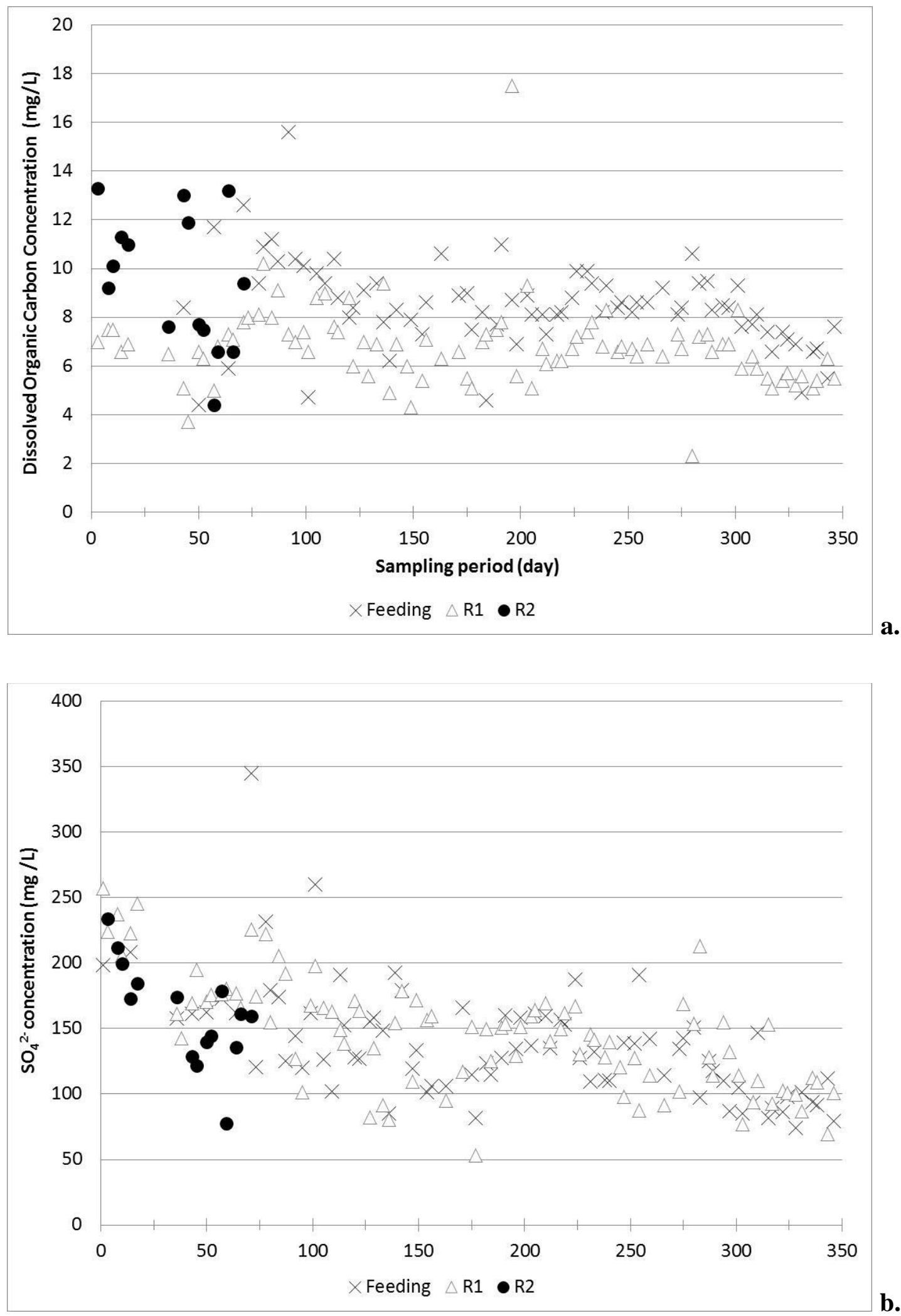

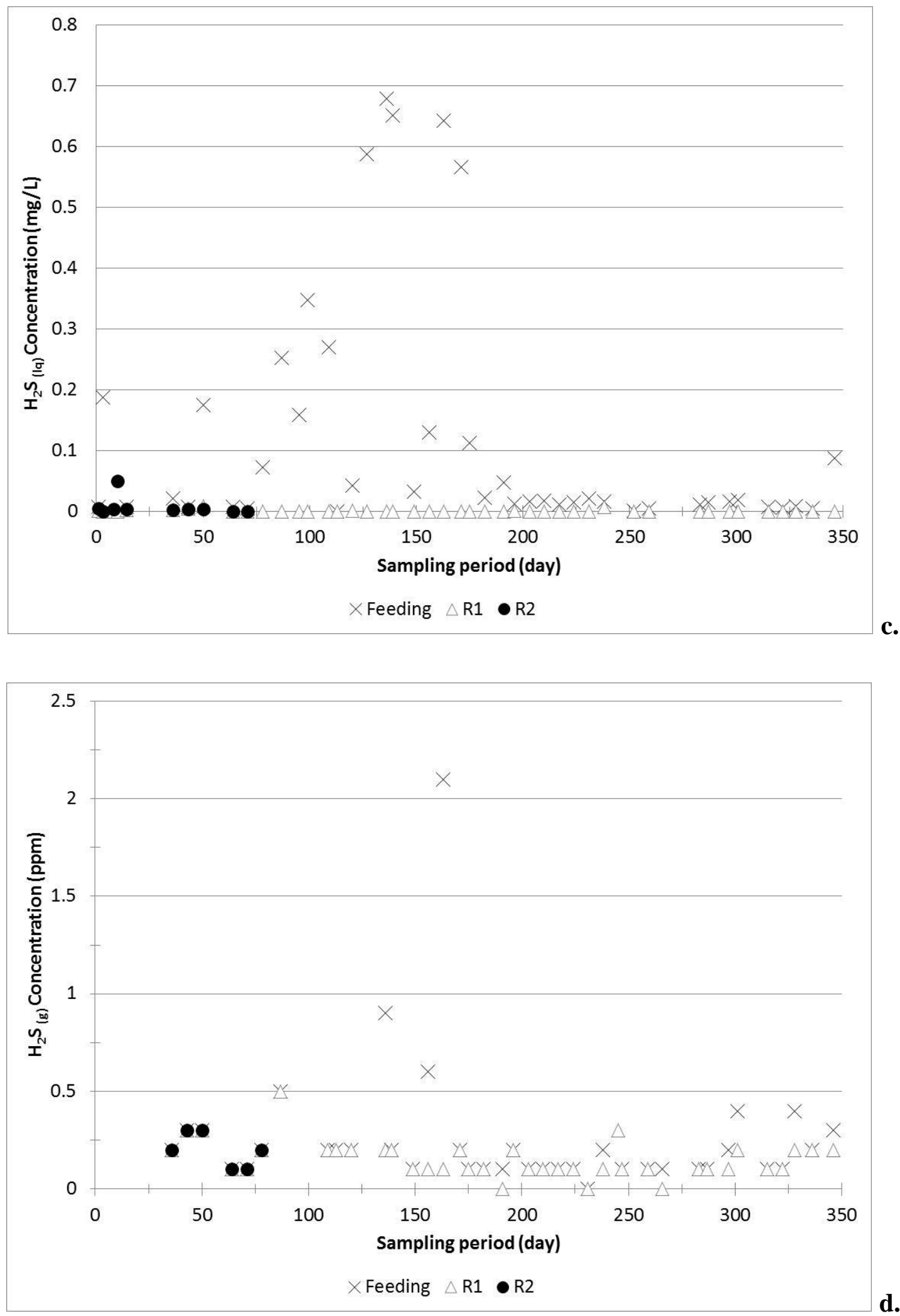

Fig. 4. 


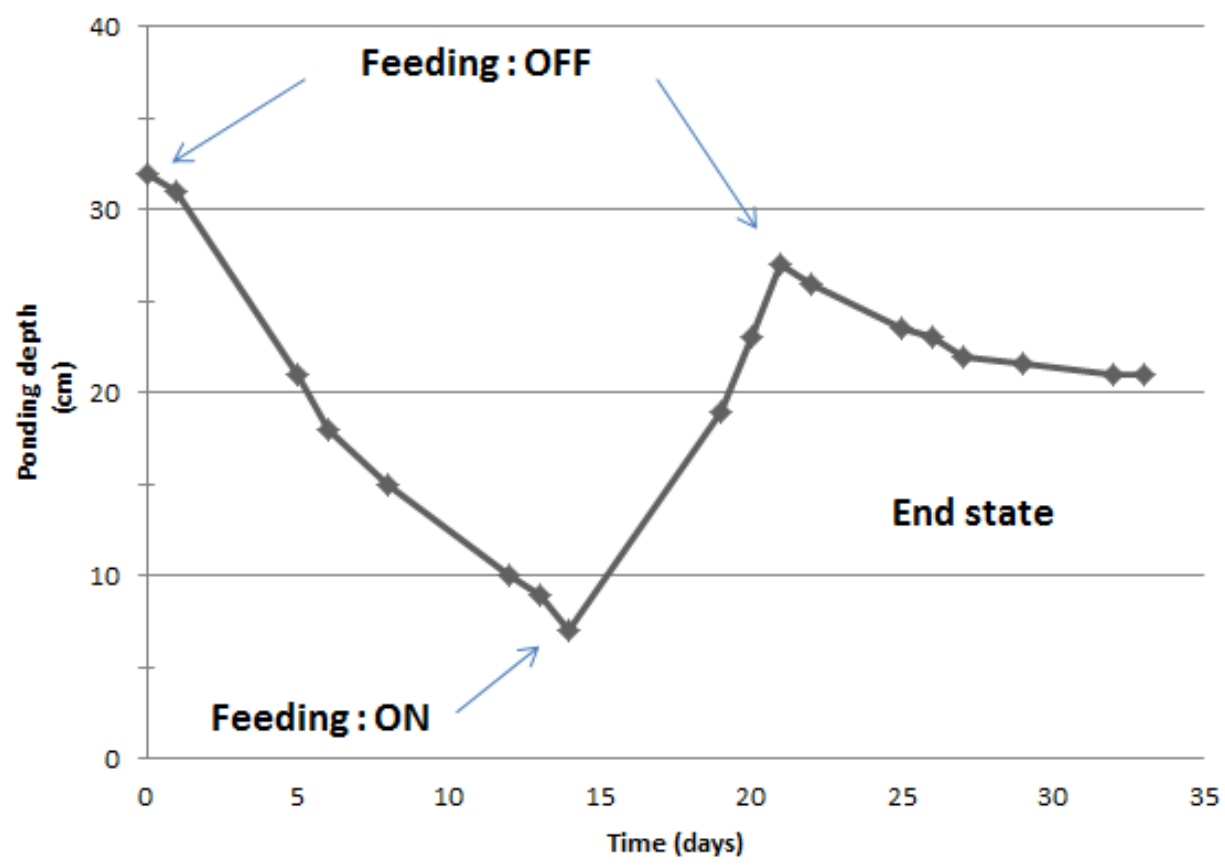

Fig. 5 


$$
\begin{array}{llllll}
\rightarrow-1 \mathrm{~cm} & -2 \mathrm{~cm} & * 3 \mathrm{~cm} & * 4 \mathrm{~cm} & \rightarrow 5 \mathrm{~cm} & +6 \mathrm{~cm} \\
-7 \mathrm{~cm} & -8 \mathrm{~cm} & \rightarrow-9 \mathrm{~cm} & \rightarrow-10 \mathrm{~cm} & \rightarrow 11 \mathrm{~cm} & -12 \mathrm{~cm} \\
-13 \mathrm{~cm} & \rightarrow-14 \mathrm{~cm} & -15 \mathrm{~cm} & -16 \mathrm{~cm} & -17 \mathrm{~cm} & \rightarrow-\text { Biomat }
\end{array}
$$

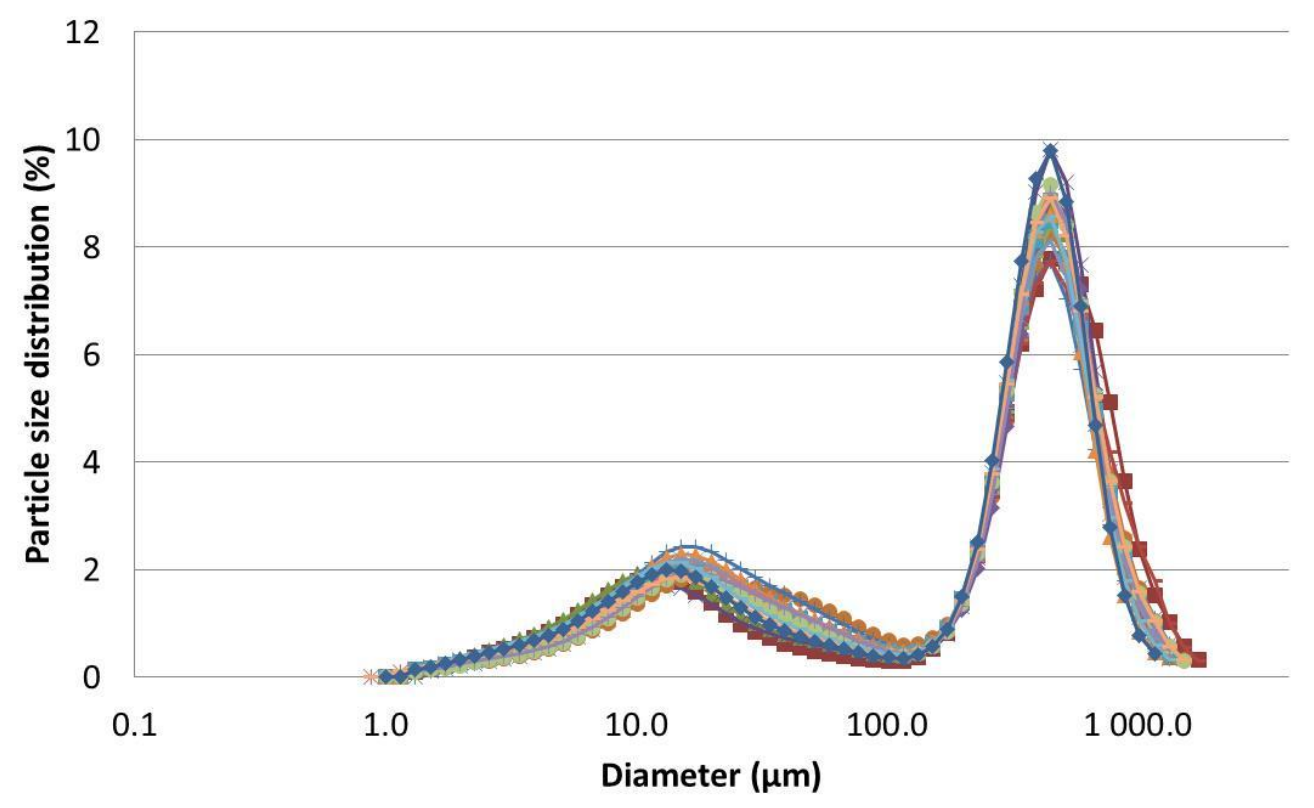

a.

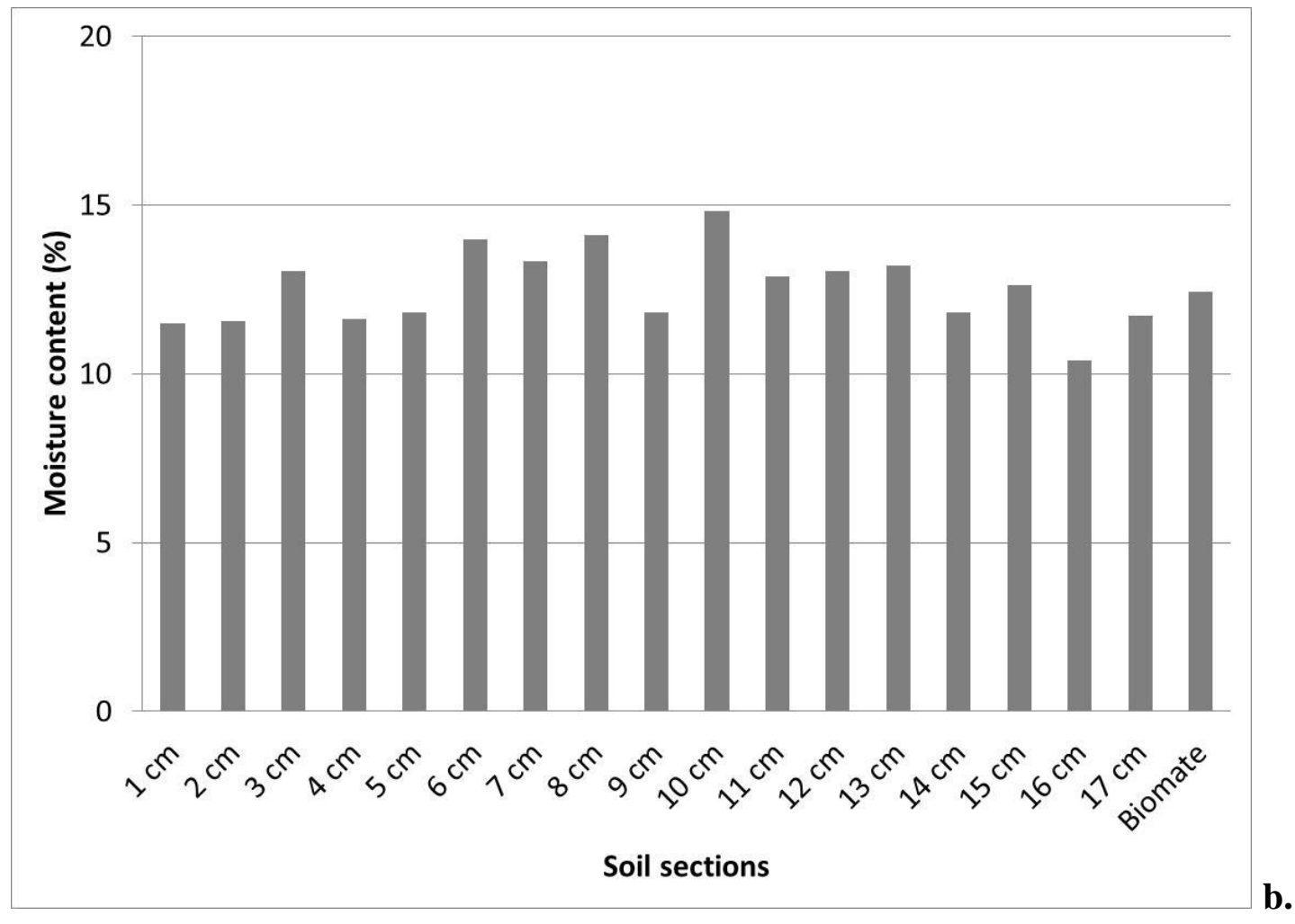




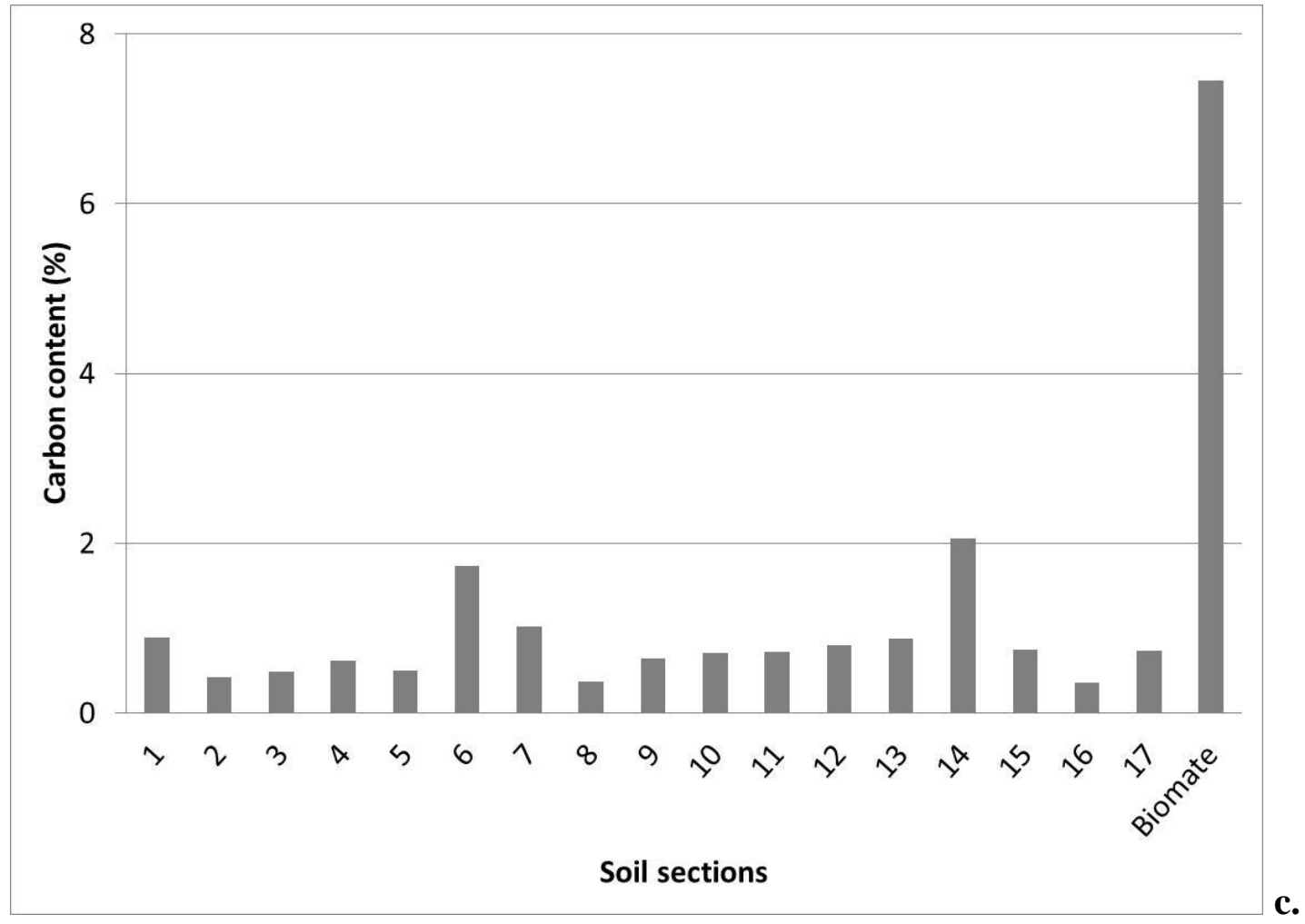

Fig. 6. 

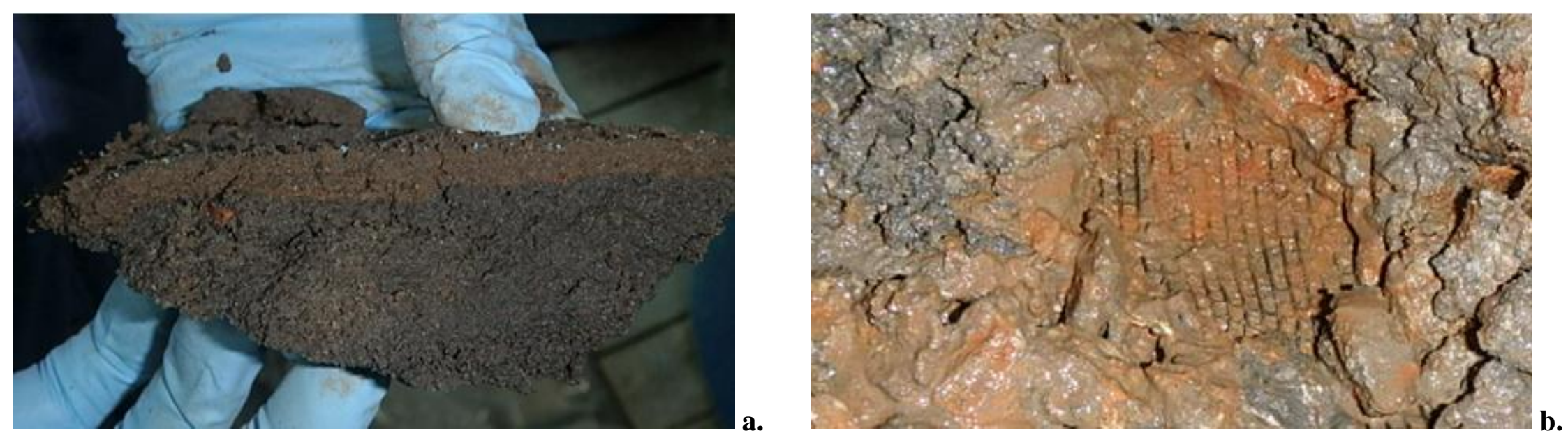

Fig. 7 
Table 1 Summary of by-products from autotrophic denitrification processes on elemental sulfur

\begin{tabular}{|c|c|c|c|c|c|}
\hline Field & Material & $\begin{array}{l}\text { Nitrate removal } \\
(\%)\end{array}$ & $\begin{array}{l}\mathrm{SO}_{4}{ }^{2-} \\
(\mathrm{mg} / \mathrm{L})\end{array}$ & $\mathrm{S}^{2-}(\mathrm{mg} / \mathrm{L})$ & Reference \\
\hline Groundwater & Egg shell & 97 & $350-450$ & Low & Xu et al. (2016) \\
\hline $\begin{array}{l}\text { Domestic } \\
\text { wastewater }\end{array}$ & Limestone & $81-99$ & $100-280$ & $\mathrm{NM}^{*}$ & Ben-Khaled (2016) \\
\hline $\begin{array}{l}\text { Aquaculture } \\
\text { wastewater }\end{array}$ & None & 50 & 136 & 0.069 & $\begin{array}{l}\text { Christianson et al. } \\
\text { (2015) }\end{array}$ \\
\hline Groundwater & Limestone & 96 & 610 & $<0.048$ & $\begin{array}{l}\text { Sierra-Alvarez et } \\
\text { al. (2007) }\end{array}$ \\
\hline Groundwater & None & 100 & 640 & $\mathrm{ND}^{* *}$ & $\begin{array}{l}\text { Kimura et al. } \\
(2002)\end{array}$ \\
\hline Groundwater & None & 80 & 320 & ND & Soares (2002) \\
\hline $\begin{array}{l}\text { Septic tank } \\
\text { effluent }\end{array}$ & Limestone & 90 & $300-400$ & $1,5-10$ & $\begin{array}{l}\text { Zhang et Shan } \\
\text { (1998) }\end{array}$ \\
\hline Groundwater & Limestone & 90 & $130-170$ & 10 & $\begin{array}{l}\text { Van Der Hoek et } \\
\text { al. (1992) }\end{array}$ \\
\hline
\end{tabular}

NM : Not mentionned ;ND : Not detected 
Table 2 Denitrified wastewater characterization and chemical composition (element concentrations expressed in mg/L) at the beginning of the experiments

\begin{tabular}{|c|c|c|c|c|c|c|c|c|c|c|c|c|c|c|c|c|c|c|c|c|c|}
\hline $\begin{array}{l}\text { Paramet } \\
\text { ers } \\
(n=92)\end{array}$ & $\mathrm{pH}$ & & $\begin{array}{l}\text { ORP } \\
(\mathrm{mV})\end{array}$ & $\begin{array}{l}\mathrm{T} \\
\text { (oC) }\end{array}$ & DO & $\begin{array}{l}\mathrm{SO}_{4}{ }^{2-} \\
(\mathrm{mg} / \mathrm{L})\end{array}$ & $\begin{array}{l}\mathrm{COD} \\
(\mathrm{mg} / \mathrm{L})\end{array}$ & $\begin{array}{l}\mathrm{H}_{2} \mathrm{~S}_{(\mathrm{g})} \\
(\mathrm{ppm})\end{array}$ & $\begin{array}{l}\mathrm{H}_{2} \mathrm{~S}_{\mathrm{ag} a \mathrm{a}} \\
(\mathrm{mg} / \mathrm{L}\end{array}$ & $\begin{array}{l}\text { DOC } \\
(\mathrm{mg} / \mathrm{L})\end{array}$ & $\begin{array}{l}\mathrm{BOD}_{5} \\
(\mathrm{mg} / \mathrm{L})\end{array}$ & $\mathrm{NO}_{3}^{-}$ & $\mathrm{Na}$ & $\mathrm{Ca}$ & $\mathrm{s}$ & $\bar{K}$ & $\mathrm{Mg}$ & Si & $P$ & $\mathrm{Fe}$ & $\overline{\mathrm{Al}}$ \\
\hline Values & $\begin{array}{l}6.7 \\
0.2\end{array}$ & \pm & $\begin{array}{l}-40 \pm \\
5\end{array}$ & 11.4 & $5.6 \pm 1.0$ & $138 \pm 43$ & $63 \pm 15$ & $0.2 \pm 0.1$ & $0.18 \pm 0.00$ & $9.8 \pm 1.8$ & $4 \pm 1$ & $5 \pm 2$ & 144 & 50.4 & 50.6 & 16.9 & 7.56 & 3.77 & 2.83 & 0.13 & 0.10 \\
\hline $\begin{array}{l}\text { Typical } \\
\text { waste- } \\
\text { water } \\
\text { values* }\end{array}$ & $\begin{array}{l}6,4 \\
7,6\end{array}$ & - & & & & $300-400$ & $<30$ & & $1.5-10$ & & & & & & & & & & & & \\
\hline
\end{tabular}

* Source: Zhang and Shan (1999) 